\title{
Energy Security And Renewable Energy Policy Analysis Of Pakistan
}

Dr. Tauseef Aized ${ }^{1}$, Dr. Amanat Ali Bhatti ${ }^{2}$, Dr. Muhammad Asif Mahmood Qureshi ${ }^{3}$ Muhammad Shahid $^{4}$, Dr. Gabrial Anandarajah ${ }^{5}$

1. Professor, Department of Mechanical Engineering, University of Engineering and Technology, Lahore, Pakistan.

Email: tauseef.aized@uet.edu.pk (correspondence author)

2. Assistant Professor, Department of Petroleum and Gas Engineering, University of Engineering and Technology, Lahore, Pakistan.

3. Assistant Professor, Department of Industrial and Manufacturing Engineering, University of Engineering and Technology, Lahore, Pakistan.

4. M.Sc. Energy Engineering candidate in Centre for Energy Research and Development, KSK campus, University of Engineering and Technology, Lahore, Pakistan.

5. Senior Lecturer, Bartlett School Env., Energy \& Resources, Faculty of the Built Environment, UCL, London, UK.

Abstract: Energy is playing a vital role to accomplish every social and industrial activity now-a-days. Ensuring sufficient energy supply has become the business of an entire society in the modern world. The successive governments of Pakistan formulated different energy security plans and polices in the past but still there is a huge gap between supply and demand; there is a shortfall of more than 5000MW of electricity in summer 2016. A policy for development of renewable energy was framed in 2006 which was aimed to supply sustainable energy to all consumers including those households which have not been supplied electricity and natural gas in rural and far-flung areas. The policy was extended for implementation in 2011 and is still in 
use. The basis of this policy rests on energy security and self-sufficiency, social equity and economic benefits. This study aims at analyzing renewable energy policy of Pakistan and examining and finding the ways to secure energy supplies in future using LEAP. Four Scenarios namely Business-as-usual, green Pakistan, nuclear and optimization have been developed to assess the validity of the energy plans.

Key Words: Energy forecasting, Electricity Scenarios, Renewable Energy Policy assessment

\section{Introduction}

The demand-supply gap of Pakistan's energy sector is increasing due to rapid population growth, adopting luxurious ways of life and improving infrastructure in all fields of life. The energy demand is increasing while supply has shown growth at snail's pace. The slow growth of energy supply is due to poor infrastructure, huge capital involved to build supply resources and delayed policies on implementation level. The demand supply gap of electricity was noted as 31.6 TWh in 2010, which resulted in 2.5\% GDP loss and unemployment of more than half million workers of industrial sector[1]. The soaring demands of the country's energy sector is met by oil, natural gas, electricity, coal and LPG. Pakistan's total energy consumption in 2010-2011 was reported as 38.8 MTOE [2] which raised to 66.8 MTOE in 2014-2015 while the estimated per capita availability of energy is $0.36 \mathrm{TOE}$ [3].Energy remained as cornerstone during country's five year plans and shifting of energy mix from cheap hydel to imported thermal due to the policies of early nineties pushed the country into energy deficit situation. The government of Pakistan formulated 'Policy for development of Renewable Energy (RE) for power generation' in 2006[4,5] which was extended and continued for additional five years [6]. Pakistan's energy sector is facing worst ever shortage of its history at the moment. The people of Pakistan bear long term electricity outages in tortuous heat of summer and natural gas shortage in cold winter. The country has significant energy reserves but vast areas of the country are deprived of commercial energy access, hence there is a dire need to develop all form of available energy [7] to reduce demand-supply gap. 
2. Related work and contribution: Global Energy sector encounter challenges related to sustainability, environment and economics. A scenario-building framework based on the Global Business Network to help energy industries to develop more resilient conservation policies subject to unpredictable and external uncertainties has been developed in $\left[{ }^{8}\right]$. A broad overview and the issues of the Power sector in Pakistan along with an analysis of the energy policies analysis and their impact on power generation sector has been presented in ${ }^{9}$.Pakistan has abundant renewable resources which are comparable with India, Bangladesh and other countries in the region [10]. The country's current energy mix, key dimensions, gap between supply and demand and potential of energy sources to meet future demand are presented in $\left[{ }^{11}\right]$. An overview of energy status and development in Pakistan is provided in [12] and the structure of electric power sector of Pakistan and a summary of historical electricity demand \& supply data, current status of divergent set of energy policies as a framework for development and application of a LEAP (Long-range Energy Alternate Planning) model of Pakistan's electric power sector has been presented in [13]. The overall condition of the electricity sector as well as the potential and recent progress in the implementation of alternative energy projects in the context of the targets set in the National Energy Security Plan (NESP) has been provided in [14].The relationship between macroeconomic factors and renewable energy in Pakistan is given in [15]. An overview of renewable energy potential in Pakistan for continuous energy sustainability has been outlined in [16] where a survey of the availability of various renewable energy sources, including hydel, solar, wind and biomass, and their current and future penetration prospects in the total energy mix have been carried out. A sizeable literature is available on energy issues of Pakistan but most of the published studies focus on single resource or consumption sector. This strategy is helpful in finding potential of resources and contribution of individual sectors but interdependence of different energy resources and consumption factors require an integrated approach. This study focuses on an integrated energy approach; all fuels like natural gas, oil, electricity, coal and LPG are included in the analysis for demand and supply forecast. This approach is helpful for investigation of dependence of the country on individual fuels. Long Range Energy 
Alternative planning system (LEAP) is the framework used for analysis to forecast demand and supply assessing the validity of electricity generation scenarios, environmental emissions and cost of electricity production in this study. Furthermore, in order to get optimized capacity and output with least cost, optimization is included in the analysis. Energy demand is forecast on the basis of previous annual compound growth rate (ACGR 2006-12). In electricity supply analysis, four scenarios i.e. Business As Usual (BAU) scenario, Green Pakistan (GP) scenario, Nuclear scenario and Optimization scenario have been developed to assess the validity of different parameters of cost, environment and generation.

\section{Energy Demand and Demand forecast:}

The major energy consumption sectors of the country include domestic, industrial, agricultural, transport, commercial, thermal power generation and other government services. Natural gas is utilized in fertilizer manufacturing industries in two ways which are termed as 'energy' and 'non-energy' use. The formation of ammonia $\left(\mathrm{NH}_{3}\right)$ and urea $\left(\mathrm{NH}_{2}\right)_{2} \mathrm{CO}$ from natural gas is categorized as non-energy use and natural gas as a fuel in fertilizer manufacturing process is called energy use. The energy use of natural gas was noted as 0.817 MTOE and non-energy use as 3.157 MTOE in 2011-12.Oil, natural gas, electricity and LPG have traditionally been used in domestic sector of Pakistan. Out of 28.19 million households where country's 180.7 million people reside, nearly one third were electrified by the end of 2011-12 [17]. Electricity is used in domestic sector for lighting, refrigeration and cooking. Oil, gas, electricity and coal have been traditional fuels used in industrial sector in the country. Brick kilns use $39 \%$ and cement manufacturing industry consumes $60 \%$ of coal. The road, rail, air and marine constitute country's transport network and the fuels used in this area during 2011-12 were aviation fuel, motor spirit, HOBC, E10, kerosene oil, high speed diesel, light diesel oil, furnace oil, electricity and natural gas. The agricultural sector consumes high speed diesel oil in tractors for which data is not available but is included in overall transport sector. Light diesel oil and electricity are also in use in agriculture sector. Energy demand forecast is developed on the bases of annual compound growth rate (ACGR) which is calculated from 2006 to2012.Use of oil and LPG in 
domestic sector is continuously decreasing due to an increase in use of natural gas and electricity. The other reason of this decrease is that the non-electrified households are being converted to electrified ones. In commercial sector, use of LPG is gradually decreasing whereas there is an increase in natural gas and electricity consumption in this area. Fossil fuels used in thermal power generation have shown mixed trends. The use of oil in this sector is gradually increasing while natural gas and coal have shown negative consumption growth indicating that their use is continuously decreasing. Table 1 provides data on energy consumed and annual compound growth rate (ACGR) of different fuels and sectors of the country.

\section{Energy Supply}

\subsection{Electricity Supply}

Electricity is generated in Pakistan through thermal, hydel and nuclear resources. Pakistan Atomic Energy Commission (PAEC), Water and Power Development Authority (WAPDA), Independent Power Producers (hydel and thermal IPPs), Generation Companies (GENCOs) and K-Electric Limited are electricity suppliers of Pakistan $\left[{ }^{18}\right]$. Most of the country supply come from thermal resources which include natural gas, oil, diesel and coal. The hydel resources are the second biggest contributor providing around $30 \%$ of the total supply. The hydel generation in the country is generated by Water and Power Development Authority (WAPDA) and Azad Jamu and Kashmir Hydro Electric Board (AJKHEB) with a total installed capacity of 6556.4 MW provided by twenty generating stations whereas the nuclear generation in the country was only $4.94 \%$ of total supply provided by Karachi nuclear power plant (KANUPP) and Chashma nuclear power plants (CHASNUPP I\&II). Total installed capacity of thermal power generation in the country during 2011-12 was 15454 MW; four plants GTPS Shahdra (44 MW), Atock Generation (165 MW), Saif Power (229 MW) and Sapphire Electric (212 MW) were dysfunctional while other forty three (43) plants with total capacity of 14803 MW were contributing in national supply but with de-rated capacity [19]. Table 2 shows energy supply data of the country. 
4.2 Coal Mining: The estimated total coal reserves of the country are 186007 million tons with 3450 million tons measured, 11677 million tones indicated, 56582 million tons inferred and 114298 million tons are hypothetical reserves. Coal reserves are found in all provinces of Pakistan. The coal found in Tharparkar desert of Sindh province has total reserves of 175.506 billion tons with dimensions of $145 \mathrm{~km}$ north-south and $65 \mathrm{~km}$ east-west which is an area of $9100 \mathrm{sq} .-\mathrm{km}$. It has low sulfur and ash content but high moisture content. Its quality is from lignite B to lignite A. The thickness of coal seams vary from 0.2 to 22.8 meters. Lignite A coal of Lakhra area has total reserves of 1328 million tons with high sulfur content. Sonda-Jerruck coal of lignite A quality has estimated total reserves of 7773 million tons. The Balochistan coal reserves are estimated as 217 million tons and it is ranked as sub-bituminous to bituminous coal. Its heating value ranges from 9637 to $15499 \mathrm{Btu} / \mathrm{lb}$. Duki, Much, Sor-range or Dargai and Khost are coal sites of Balochistan with 56, 23, 50 and 88 million tons of coal reserves respectively. The salt-range and Makarwal coal of Punjab is of sub-bituminous category with calorific value of $9472-15801 \mathrm{Btu} / \mathrm{lb}$. Total coal reserves of the salt range is 213 million tons and Makarwal is 22 million tons. Hangu and Cherat are two coal sites of KPK with 91 million tons of estimated total coal reserves. Sub-bituminous coal is found in KPK with heating value ranges from $9386 \mathrm{Btu} / \mathrm{lb}$. to $14217 \mathrm{Btu} / \mathrm{lb}$. It has low sulfur and low ash content. The estimated coal reserves of AJK are only 9 million tons whereas coal bed has an average thickness of 0.6 meter. During 2011-12, the production of coal was recorded as 3.61 million tons whereas total imports in the country was 4.05 million tons $\left[{ }^{20}\right]$. Table 3 explains coal properties from all mines of Pakistan.

\subsection{Oil and natural gas sector:}

Pakistan's recoverable reserves of crude oil was estimated as 371.029 million barrels in 2013 and oil refining capacity in 2012 was 13.08 million tons per year while it was 18.79 million tonnes per year in 2013. The country's crude oil has been refined in six refineries i.e. Attock, Bosicor, ENER Petrotech, National, PakArab during 2011-12 amounting to 9.19 million tons whereas it had been 11.24 million tonnes during 20067 , thus showing an annual compound growth rate of $-4.0 \%$ [9]. The crude oil refined in the country consists 
of both indigenous and imported crude oil with 3 and 6.1 millions tonnes refining respectively. The main users of petroleum products in the country are power and transport sectors which consume approximately $90 \%$ of petroleum products.

The natural gas potential of the country was estimated as 282 trillion cubic feet during 2012-13 whereas recoverable reserves were only 24 trillion cubic feet $\left[{ }^{21}\right]$. The production of natural gas from associated and non-associated gas fields during 2011-12 was 1558959 million cubic feet or 32.04 MTOE whereas annual compound growth rate for natural gas production was 2\% during 2006-12 [13]. There are 146 non-associated and 44 associated gas fields in the country and total daily production is 4092 million cubic feet[22].The share of natural gas in Pakistan's primary energy supply was $32 \%$ in 2012. The production was estimated 809 billion cubic feet (Bcf) in 2002 and 1412 Bcf in 2013, thus showing an increase of more than $80 \%$, whereas shortfall recorded by the government of Pakistan in 2013 was 912 Bcf[23]. To combat natural gas shortfall, the government of Pakistan has set priority for supply of natural gas to different category of consumers. The top priority is given to domestic and commercial sector indicating that government is much interested in addressing socio-economic dynamics to ensure livelihood for people of Pakistan. The second priority is given to power sector indicating effective polices of government to minimize energy crises [53]. The overall priority chart of different sectors is shown in Table 4 [14].

To promote green energy and reduce dependence on petroleum products, compressed natural gas (CNG) was introduced in the country during 1992.For few years, CNG sector has seen tremendous growth and now Pakistan is among world leading CNG user countries. The country has more than 3 million NGVs (natural gas vehicles) and 3414 CNG stations for fueling NGVs. Realizing the gas situation in the country, the federal government has imposed a ban for issuance of license to open new CNG station throughout the country. Pakistan has pursued 750 MMCFD (million cubic feet per day) Liquefied Natural Gas (LNG) pipeline from 
Iran and 1325 MMCFD Turkmenistan-Afghanistan-Pakistan-India (TAPI) gas pipeline. These two projects are in pipeline for more than two decades due to sanctions on Iran and security situation in Afghanistan. The government of Pakistan has lately been successful to import 500 MMCFD LNG from Qatar.

The share of LPG in primary energy supply is only $0.5 \%$ but its importance from national prospective is vital as it preserve forest cover which is already very low, that is, only $2.1 \%$ [15]. According to economic survey of Pakistan 2011-12, only 6 million houses are connected to natural gas supply network while the rest use LPG, wood, animal dung, waste agricultural biomass, coal and kerosene oil [2]. The geography of the country along with natural gas reserves does not allow 100 percent domestic natural gas connections, however LPG can be used as an alternative fuel and it also reduces deforestation [13]. During 2011-2012, the total LPG supply to the country was 466389 tonnes or 504586 TOE in which 169005 tonnes were supplied by refineries, 217048 tonnes were produced by field plants and only 80336 tonnes were imported. Annual compound growth rate of refineries and plants has shown negative growth of 4.4 and 10.2 percent while import has indicated positive growth of $4.1 \%$ [41]. In terms of percentage, 46.54 percent was produced by field plants, $36.24 \%$ was supplied by refineries and $17.22 \%$ was imported [41]. During 2014-15, field plants production was indicated as $53 \%$ whereas refineries and imports share in production was $26 \%$ and $21 \%$ respectively [15].

\subsection{Projection of Coal mining, Oil refining, Natural Gas and LPG Production:}

The production of oil refining, coal mining, natural gas and LPG is projected on the basis of simple plans of Government, simple assumption or ACGR calculated on the basis of previous data. Process share, process efficiency and capacity credit for all involved processes is assumed as $100 \%$. Historical production and exogenous capacity of all processes is elaborated in Table 5.

\section{LEAP Model for Pakistan:}


Long Range Energy Alternative Planning (LEAP) System has been used in this study to forecast energy demand, analyze the electricity generation technologies, optimize the generation systems of different scenarios and projection of oil refining, coal mining, natural gas production and LPG production. Figure 1 elaborates framework for Pakistan’s LEAP Model. Four scenarios namely Business As Usual, Green Pakistan, Nuclear and optimization have been developed based on data for Pakistan's electricity system. The year 2011 is used as base year for all energy pathways. Business As Usual scenario is an energy pathway based on the data of energy year book published every year in the country and Green Pakistan Scenario is a pathways which is based on the plans of policy for development of Renewable Energy for power generation 2006 and Alternative and Renewable Energy policy 2011[24]. In this model, demand section is formulated on econometric top-down approach in which energy consumption is broken down into sectors and branches. Future forecast of consumption trends is based on simple aggregate econometric relationships [25] i.e. GDP, fuel prices etc. The demand projection of this analysis is mostly dependent on energy intensive growth rate of branches and least dependent on sector's growth rate. The energy generation is dependent on its usage, that is, there will be no production in LEAP if there is no usage. For demand analysis, total energy usage of every fuel was available which was summed up to find final energy demand. To meet the demand, in LEAP model, technologies are dispatched based on each pathway requirement. In transformation sections, each module has one or more feedstock fuels and different technologies like coal combustion turbine, gas combustion turbines, oil combustion turbines, co-generation turbines, hydroelectric generation turbine and nuclear generation technologies. Plants installed under renewable energy policy (REP Generation) consists of small hydro, wind and solar technologies. For each technology, dispatch rule, historical production, process efficiency, endogenous capacity, exogenous capacity, maximum availability, life time of the plant, capital cost, fixed O\&M (operation \& maintenance) cost, variable operation and maintenance cost and fuel cost are required. On supply side of LEAP model, old capacities are retired exogenously while new capacities are added exogenously and endogenously to the power sector infrastructure. These plans are based on demand side 
requirements, costs of plants and externality costs. This study also analyses greenhouse gases emissions linked with each fuel type for the power generation in Pakistan. Technology and environment database (TED) is embedded in the LEAP system.

\subsection{Assumptions and limitations in LEAP Model:}

The Business As Usual and Nuclear scenarios have been developed based on GDP growth rate of the country which was $3.7 \%$ in 2011 and $4.24 \%$ in 2014-15. Additionally, a 5\% GDP growth rate is considered for development of Green Pakistan pathway and optimization pathways $\left[{ }^{26}\right]$. Transmission and distribution (T\&D) losses were $25 \%$ in 2012 and it is a plan of NEPRA to reduce these losses to $16 \%$ until 2017 with a further decrease to $10.4 \%$ by 2030 [27]. T \& D losses of natural gas supply are $0.4 \%$ and oil products are $0.2 \%$ [28], it is assumed that these losses will sustain during the period considered. Energy delivered to DISCOs during 2011-12 is used to construct load shape for Pakistan [29]. Greenhouse gases emissions and environmental parameters are assumed on the basis of tier 1 emission factors as detailed by Intergovernmental Panel on Climate Change (IPCC)[30]. Stranded costs which represent sunk cost are assumed to be zero, discount rate is $5 \%$ and the salvage value is considered to be 10 percent of capital cost of the power plant[31].

There are several data and computerized framework limitations in this analysis including spatial analysis of power plants along with transmission and distribution network which is not considered in this model, instead total transmission and distribution losses have been considered. During model development, it has been assumed that the supply of generated electricity can be transmitted to any load station at any time without any constraint. Few data are available about lifespan of private thermal power plants, therefore retirements of plants are made purely on the bases of data available for public sector power plants. The optimization modelling is based on current account and prefers cheap technologies. Another limitation of LEAP model is related to Open Source Energy Modelling System (OSeMOSYS) which does not support zero discount rate [32]. The LEAP model does not calculate hourly load profile, instead it considers annual generation profile. 
This limitation ignores the environmental effects on generation of renewable energy technologies like wind, solar and hydel generation. Four scenarios entitled, Business-as-usual (BAU), Green Pakistan (GP), Nuclear Scenario (NS) and optimization have been developed in this study. The BAU is based on current government policies and plans. Particularly present to near future data is included in this scenario. This pathway will depict socio-economic and environmental impacts of government policies on the energy sector of Pakistan. GDP growth rate of Pakistan was noted as $4.24 \%$ in 2015 and same growth rate is assumed for the whole study period. Electricity transmission and distribution losses was $25 \%$ in 2011 whereas plan of government is to reduce these losses to $16 \%$ in 2017 and up to $10 \%$ in 2030. In Green Pakistan (GP) scenario, it is assumed that the capacity of renewables will generate electricity while maximum availability and costs of thermal and nuclear capacity will be reduced to zero so that their capacities can't take part in generation and cost of generation. This is a reflection of recent government policy which places greater emphasis on renewable energy and it was a plan of government to include $10 \%$ renewable energy or $2700 \mathrm{MW}$ in the energy mix of country by 2015 . However, this target was not achieved. Additionally, the target fixed by Alternative and Renewable Energy Policy 2011 and RE policy 2006 was that at least 9700 MW capacity must be installed by 2030. Pakistan Atomic Energy Commission (PAEC) under the aegis of Government of Pakistan wants to install 8800 MW nuclear power reactors by 2030 and a Nuclear Scenario has been developed in this study which assumes that the generation will only be possible from nuclear installed capacity. Both GP and NS are hypothetical scenarios based on the idea of analyzing the possibility to shut down all other capacities except renewables and nuclear ones respectively. Optimization Scenario is included in the system to assess least cost capacity expansion and generation calculations. This scenario is different from all other scenarios as it is constructed on current account. Therefore, demand remains same during the whole study period and this scenario does not allow old capacity to retire which is a typical assumption of LEAP tool.

\section{LEAP modelling results and discussion:}


The demand forecasting of Pakistan is carried out by growth rate in demands. All the fuels used in different sectors are not positively increasing. Oil and LPG use has decreased in domestic sector, whereas use of oil and gas has decreased in industrial sector. Oil is being less frequently used in agriculture and other government services. During 2006-11, natural gas as a fuel in fertilizer sector has witnessed negative growth; however total demand of energy and non-energy in the country is gradually increasing. Figures $2 \& 3$ explain demand forecast of all energy consuming sectors and fuels respectively. Figures 4 through 7 provide information on capacities and figures 8 through 11 provide electricity supply information in all four scenarios whereas table 7 shows numerical data for electrical energy installed capacities and their generated outputs. Figures 12 through 15 and table 8 provide cost of production data. The global warming potential caused in BAU scenario is given in figure 16 whereas all energy supply forecast other than electricity is given in figure 17 and table 9.

\section{Discussion on LEAP results:}

Total energy and non-energy demand of Pakistan is gradually increasing from 2012 to 2030. In 2012, total consumption of Pakistan was 59.3 MTOE out of which 3.2 MTOE was non-energy use of natural gas. Energy consumption in domestic sector is gradually increasing from 9.8 MTOE in 2012 to 26.3 MTOE in 2030. This consumption include oil, natural gas, LPG and electricity. Energy consumption in production industries is gradually decreasing due to negative growth of oil, natural gas and coal. It was estimated 14.9 MTOE in 2012 and will be 12.7 MTOE in 2030. Energy consumption in transport sector is gradually increasing from 13.3 MTOE in 2012 to 64.6 MTOE in 2030. Natural gas and oil are major contributor of transport sector and their consumption is gradually increasing. In thermal power generation sector, energy consumption is increasing from 14.0 MTOE in 2012 to only14.2 MTOE in 2030 because the future expansion in this sector is planned on the basis of LNG, coal and natural gas based power generation. Energy consumption in commercial sector is gradually increasing from 1.6 MTOE in 2012 to 3.0 MTOE in 2030. In fertilizer sector, more natural gas is consumed as non-energy usage and less in energy usage. Non-energy use of natural gas is gradually increasing from 3.2 MTOE in 2012 to 3.9 MTOE in 2030 while its energy usage is increasing from 0.8 MTOE in 2012 
to 1.0 MTOE. In terms of fuels, electricity consumption is increasing from 6.5 MTOE in 2012 to 9.3 MTOE in 2030 in all the sectors of Pakistan, natural gas consumption is increasing from 28.9 MTOE in 2012 to 85.8 MTOE in 2030, LPG consumption is increasing from 0.5 to 3.1 MTOE during the study period. Consumption of oil is gradually increasing from 19.4 MTOE in 2012 to 29.9 MTOE in 2030 in all the sectors of Pakistan whereas total production and refining capacity of the country is not increasing compare able with the consumption. Coal consumption was noted as 4.0 MTOE in 2012 while it will be 3.8 MTOE in 2030, although this consumption is bound to increase with the newly built coal based plants in near future. The capacity of BAU scenario has increased from $23.7 \mathrm{GW}$ in 2012 to $26.7 \mathrm{GW}$ in 2030 during the whole study period. This scenario has diversity of energy mix and includes nuclear and thermal process along with renewables. The capacity in BAU is not only producing electricity according to demands but also some capacity is in reserved state. Green Pakistan and nuclear scenarios have limited capacity according to government plans. The capacity in green Pakistan scenario is gradually increasing from $7.1 \mathrm{GW}$ in 2012 to $14.9 \mathrm{GW}$ in 2030 whereas the capacity in nuclear scenario is gradually increasing from $1.3 \mathrm{GW}$ in 2012 to $9.5 \mathrm{GW}$ in 2030.

The optimized capacities were $35.3 \mathrm{GW}$ and $38.4 \mathrm{GW}$ and total electric energy outputs were 6.6 MTOE and 7.2 MTOE in 2012 and 2030 respectively. The optimization scenario, based on least cost, is showing a threefold increase in hydel capacity to meet national demand as it increases from $6.5 \mathrm{GW}$ in 2011 to $22.7 \mathrm{GW}$ in 2016 and is maintained up to 2030. Capital Costs are directly linked with capacity, as soon as capacity increases costs increase and with the passage of time cost decreases. Externality costs are dependent on generation, thermal generation is the cause of this cost due to environmental emissions. Green Pakistan scenario and nuclear scenario has no environmental emissions therefore externality costs are reduced to zero in these scenarios. Renewables like wind, hydel and solar has no fuel cost. For better comparison, unit MTOE costs are calculated in all scenarios. In optimization, system is optimized in 2012 and with the passage of time costs decreases. Basically optimization in LEAP calculates least costs and leads us to those options which 
provide us maximum output at least costs but it ignores the reality of circumstances. For example, in our system it improves hydel capacity from 6.5 thousand MW in 2011 to 19.7 thousand MW in 2012 on the payment of 1632.5 million US dollars which are very low as compare to actual cost. Moreover, it does not take into account the capital costs of furnace oil generation, high speed diesel generation, nuclear generation and thermal gas generation etc. and gets output on the basis of other costs. However, it provides best point to find least cost capacity expansion. Per MTOE electricity generation costs are 1204.69 MUSD (million US dollars), 121.71 MUSD, 650.87 MUSD and 421.61 MUSD in 2012 in BAU, GP, NS, and Optimization scenarios respectively. The point worth noting is that per MTOE electricity generation cost of Green Pakistan scenario is even lower than the optimization scenario. In 2020 per MTOE electricity generation costs are 942.49 MUSD in BAU, 213.27 MUSD in GP, 559.39 MUSD in NS and 296.71 MUSD in optimization scenario. Again GP scenario cost is not only lower than optimization scenario but also about one fourth of BAU and lower than half of nuclear scenario. In 2030 per MTOE costs of BAU, GP, nuclear and optimization scenarios are 723.98 MUSD, 171.28 MUSD, 353.29 MUSD and 179.47 MUSD respectively. This clearly indicates that electricity generation costs are the lowest by renewables, though capital costs are high but long term cost calculations including environmental emissions leads us to a single point i.e. renewables are the best. System optimization also points out to hydel generation as there is no environmental and fuel costs in renewables.

One hundred year GWP due to electricity generation by running processes (figure 6) is gradually increasing from 22.2 million metric tons $\mathrm{CO}_{2}$ equivalent in 2012 to 55.2 million metric tons $\mathrm{CO}_{2}$ equivalent in 2030 in Business as Usual scenario. Green Pakistan and Nuclear scenarios have no environmental emissions during operation. Optimization scenario has limited emissions. In this global warming potential more than $99 \%$ Global Warming is due to carbon dioxide emissions and less than $1 \%$ due to methane and nitrous oxide. 
Supply forecast of oil, coal natural gas and LPG is shown in figure 7 and numerical values of these fuels are shown in Table 12.

Coal is consumed in brick kiln power and cement industry and its consumption is gradually decreasing from 4.0 to 3.8 MTOE in the study period (table 9). It can be supplied from 8.7 MTOE in 2012 to 18.5 MTOE in 2030 easily as its capacity is abundant in Pakistan but due to lack of technology it is also imported. Demand of natural gas is increasing from 28.9 MTOE in 2012 to 85.8 MTOE in 2030 while it can be supplied from 33.6 MTOE in 2012 to 87.8 MTOE in 2030 and after losses it will fulfill the demands.

Government of Pakistan is also importing LNG from Qatar to reduce indigenous depletion of wells. LPG is obtained from refineries, field plants and imports and its demand is more than its production in the country. It is a green fuel and reduces deforestation in the country. Demand of oil is more than its production and refining. Its demand is increasing from 19.4 MTOE to 29.9 MTOE while present oil refining capacity in the country is only 18.8 MTOE. This capacity cannot fulfill the demands of the whole nation. Pakistan already imports more crude oil than its indigenous crude oil production and minimum refining capacity compels the country to import refined oil which puts an extra burden on national exchequer. Moreover, it is also a source of electricity crises in the country. Even in 2030, 6417 MW thermal oil capacity will be available while generation from this capacity will be only 0.7 MTOE which clearly indicates that generation from oil is costly process and our country is reluctant, even after installing the capacity to generate electricity from oil due to fuel prices. For example, 2360.9 MUSD were paid in 2012 to purchase furnace oil which generated 0.7 MTOE electricity. This strengthen the opinion of general public that GOP has no capacity shortfall that's why in a government specific day electricity is fed to the whole nation but continuous use of expensive fuels improves the generation cost which becomes difficult to collect and government apply load management strategies which hampers GDP growth rate. Power sector and transport jointly consumes more than $90 \%$ of oil products in the country. Therefore, it is dire need of time to reduce our dependence on oil and find alternative sources of energy. 


\section{Conclusion}

Pakistan's demand supply forecast is clearly indicating its dependence on fossil fuels which is alarming situation. In 2030 Pakistan's total demand will be 131.8 MTOE in which oil demand will be 29.9 MTOE which is even higher than all refining capacity of the country and natural gas demand will be 85.8 MTOE leading the depletion of known reserves within five years. It clearly concludes that we should revisit our policies. We should minimize our dependence on oil and find new means of energy which will be sustainable and environmental friendly. Electricity generation by oil must be changed by renewables and biofuels must be promoted for transport sector. Pakistan has abundant coal reserves but its share in energy mix of the country is dismal, however this share must be increased after functioning of coal based electricity generation capacity. Demand of LPG is more than its production and by installing more oil refining capacity its output must be increased. One hundred years global warming potential due to electricity generation is increasing from 22.2 million metric tons $\mathrm{CO}_{2}$ equivalents in 2012 to 55.2 million metric tons $\mathrm{CO}_{2}$ equivalent in 2030. This increasing potential is definitely a potential threat for food security, water security and health security of the people of Pakistan. Therefore, it is dire need of time to increase our dependence on renewables not only for power generation but also for transportation and other social services. The share of renewable energy in power generation must be more than $10 \%$ until 2030. Scenario analysis with cost and environment clearly indicates that electricity generation by renewables is the best option for our country. However capital costs of renewable energy technologies are high as compared to thermal technologies. Each scenario has its own advantages and disadvantages, Optimization scenario is constructed on current account therefore it does not take into account the gradual increase in demand. Optimized capacity is obtained within three years and its output first increases and then decreases with the passage of time. Optimization takes place on the basis of least cost and it concludes that how our output can be increased by least cost. This scenario ignores the retirement of power plants and pays only fuel and maintenance costs to obtain the output from existing plants. However, output in this scenario is even higher than BAU scenario. Business as Usual (BAU) scenario represents diversity of energy mix but is the most expensive scenario in the system. It's unit MTOE electricity generation cost ranges from 1204.69 MUSD in 2012 to 723.98 MUSD in 2030 whereas its capital cost first increases when new capacity is installed and then gradually decreases. Its externality costs also show increasing and decreasing trend due to increasing and decreasing dependence on thermal generation. Externality costs are very high ranging from 1866.4 to 2082.8 MUSD during the study period, indicating that our policies must be revisited to save the environment and more capacity must be installed to increase the share of renewables in electricity supply. This will not only beneficial for environment but also saves capital which is consumed as fuel cost. Green 
Pakistan scenario is obeying renewable energy policy plans; therefore, low capacity is installed in this scenario. For comparison of results per MTOE electricity generation costs are calculated which are lowest in this scenario. Basically renewable electricity generation technologies are functional on those fuels which have no fuel cost and as these fuels have no environmental emissions therefore have no externality costs which makes renewable electricity generation the cheapest in the system. In this scenario new capacity is continuously installed to pursue the targets therefore per MTOE electricity generation cost ranges from 121.7 MUSD in 2012 to 171.7 MUSD in 2030. Nuclear Technologies along with renewables must be promoted in the country for clean and sustainable energy generation. The shifting of thermal oil to coal must include the abatement cost to save the environment. In the nutshell it can be concluded that integrated energy policy including all fuels and all sectors should be drafted to change the energy dynamics of Pakistan.

\section{References}

1. Usama P, Ahmed S, S Fahad H, Usman Z. The long-term forecast of Pakistan's electricity supply and demand: An application of long range energy alternatives planning. Energy 2015, 2423-2435.

2. GOP, Pakistan Economic Survey 2011-12, Economic Advisor's Wing, Ministry of Finance, Government of Pakistan (GOP), Islamabad., 2012.

3. GOP, Pakistan Economic Survey 2014-15, Economic Advisor's Wing, Ministry of Finance, Government of Pakistan (GOP), Islamabad, 2015.

4. GOP, Policy for Development of Renewable Energy for Power Generation, Ministry for water and Power, Government of Pakistan, 2006.

5. SAARC CCI, Energy policy in South Asia: The Way Forward to Prompt Regional Trade, SAARC Chamber of Commerce and Industry; 2012, P\# 14.

6. AEDB, Alternative Energy Development Board (AEDB), Ministry of Water and Power Government of Pakistan, 2016. [Online].Available: /http: // www.aedb.org). [Accessed: 15-Dec-2015].

7. PIDE, Pakistan's Energy Sector: From Crises to Crises Breaking the Chain. Pakistan Institute of Development Economics Islamabad; 2012.

8. Alizadeh, R., Lund, P.D. , Beynaghi, A., Abolghasemi, M., Maknoon, R. An integrated scenario-based robust planning approach for foresight and strategic management with application to energy industry. Technological Forecasting \& Social Change 104 (2016) 162-171.

9. RukhShakeel, S., JosuTakala, Shakeel, W. Renewable energy sources in power generation in Pakistan. RenewableandSustainableEnergyReviews64(2016)421-434.

10. Khare Vikas, Nema Savita, Baredar Prashant. Status of solar wind renewable energy in India. Renewable and Sustainable Energy Reviews (27): 1-10; 2013. 
11. Wakeel, M., Chen, B., Jahangir, S. Overview of energy portfolio in Pakistan. Energy Procedia 88 ( 2016 ) 71 - 75.

12. Omer Rauf , Shujie Wang, Peng Yuan, Junzhe Tan, An overview of energy status and development in Pakistan. Renewable and Sustainable Energy Reviews, Volume 48, August 2015, Pages 892-931.

- 13. Usama Perwez' , Ahmed Sohail, Syed Fahad Hassan, Usman Zia ' The long-term forecast of Pakistan's electricity supply and demand: An application of long range energy alternatives planning' Energy Volume 93, Part 2, 15 December 2015, Pages 2423-2435.

14. Faheemullah Shaikh' Qiang Ji,Ying Fan' The diagnosis of an electricity crisis and alternative energy development in Pakistan. Renewable and Sustainable Energy Reviews

Volume 52, December 2015, Pages 1172-1185

15. Ihtisham Abdul Malik, Ghamz-e-Ali Siyal, Alias Bin Abdullah, Arif Alam, Khalid Zaman ,Phouphet Kyophilavong, Muhammad Shahbaz, Siraj Ullah Baloch, Tauqeer Shams, Turn on the lights:

Macroeconomic factors affecting renewable energy in Pakistan. Renewable and Sustainable Energy

Reviews, Volume 38, October 2014, Pages 277-284

16.Abdul Ghafoor, Tanzeel ur Rehman, Anjum Munir, Manzoor Ahmad, Muhammad Iqbal. Current status and overview of renewable energy potential in Pakistan for continuous energy sustainability. Renewable and Sustainable Energy Reviews, Volume 60, July 2016, Pages 1332-1342

17 . GOP, Household Integrated Economic Survey 2011-12, Statistics Division, Pakistan Bureau of Statistics, Government of Pakistan, Islamabad, 2013.

18. NEPRA, State of Industry Report 2014, National Electric Power Regulatory Authority (NEPRA). Ministry of water and power development, Government of Pakistan, Islamabad: 2015.

19. NEPRA, State of Industry Report 2012, National Electric Power Regulatory Authority (NEPRA). Ministry of water and power development, Government of Pakistan, Islamabad: 2012.

20. NEPRA, State of Industry Report 2013, National Electric Power Regulatory Authority (NEPRA). Ministry of water and power development, Government of ; Pakistan, Islamabad: 2013.

21. GOP, Pakistan Economic Survey 2012-13, Economic Advisor's Wing, Ministry of Finance, Government of Pakistan (GOP), Islamabad, 2013: Ch. \# 14.

22. GOP, Pakistan Petroleum Sector quarterly Report of 10 April 2015, Monitoring and Evaluation Unit, Government of Pakistan; P\#2-3

23. Pakistan: International energy data and Analysis, [Online].Available at: https://www.eia.gov/beta/international/analysis.cfm?iso=PAK

24. GOP, Alternative and Renewable Energy Policy 2011, Ministry for water and Power, Government of Pakistan, 2011.

25. SEI; LEAP A Tool for Energy Planning and GHG Mitigation Assessment; Stockholm Environment Institute, (SEI).

26. Pakistan Economic Survey 2014-15, Economic Advisor's Wing, Ministry of Finance, Government of Pakistan (GOP), Islamabad, 2015.

27. NTDC, Electricity demand forecast based on multiple regression analysis. National Transmission and Despatch Company of Pakistan (NTDC) 2012. 
28. Muhammad Khalid F, S.Kumar. An assessment of renewable energy potential for electricity generation in Pakistan; Renewable and Sustainable Energy Reviews (20): 240-254; 2013.

29. PPIB, Annual Report 2012-13, Private Power and Infrastructure Board, Government of Pakistan;P\#42.

30. IPCC (Intergovernmental Panel on Climate Change). Revised 1996 IPCC guidelines for national greenhouse gas inventories, vol. $3 ; 1996$.

31. Kale RV, Pohekar SD. Electricity demand and supply scenarios for Maharashtra (India) for 2030: an application of long range energy alternatives planning. Energy Policy 2014:1-13.

32. USAID, Training Workshop on Using LEAP for Energy and Climate Change Mitigation Assessment;

Technical Training. Analysis and Investment for Low Emission Growth (AILEG); 2013.

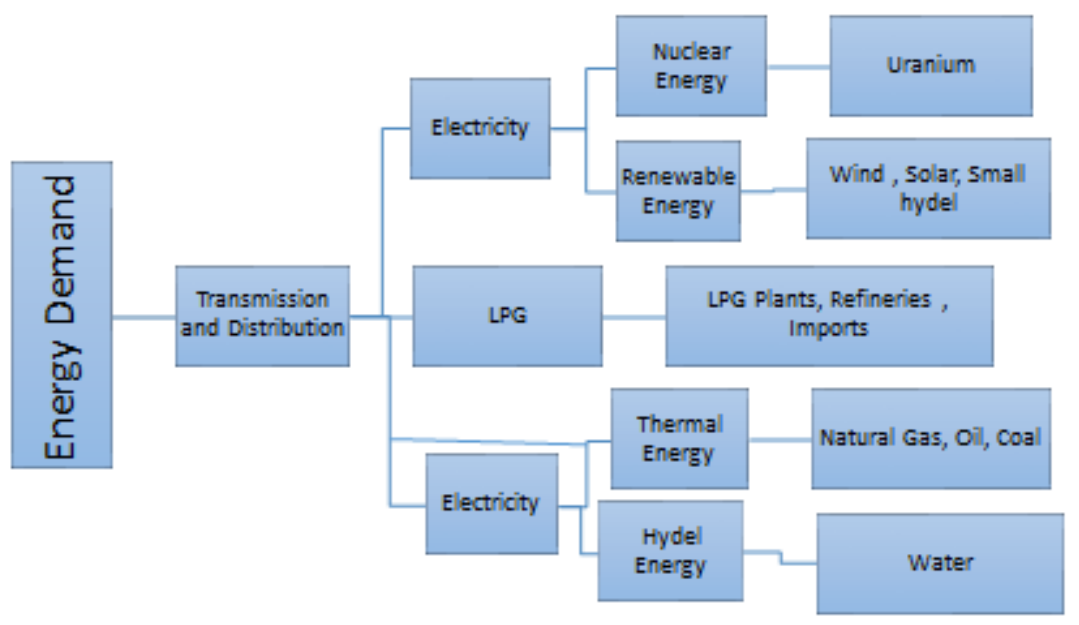

Figure: 1 Energy Module Framework for Pakistan's LEAP Model. 
Sectoral View of Pakistan's Demand

All Branches

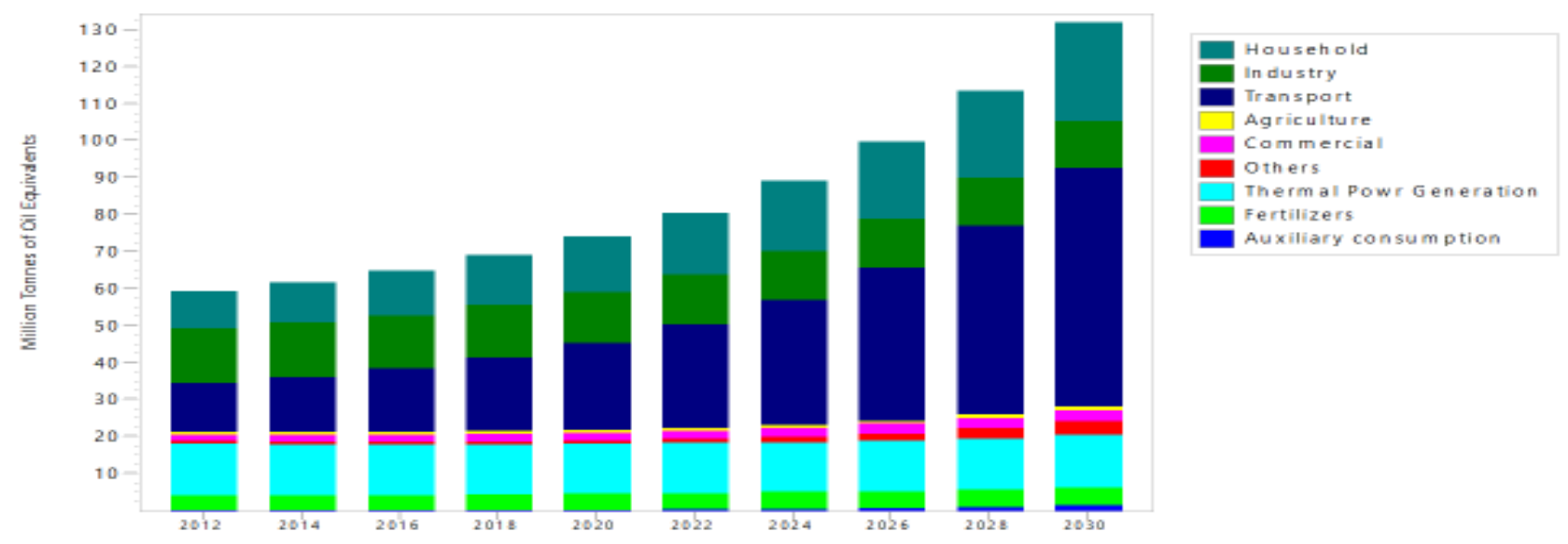

Figure 2: Sectoral view of Pakistan's demand forecast.

Pakistan's demand forecast by fuels

All fuels including all types of coal in coal lignite

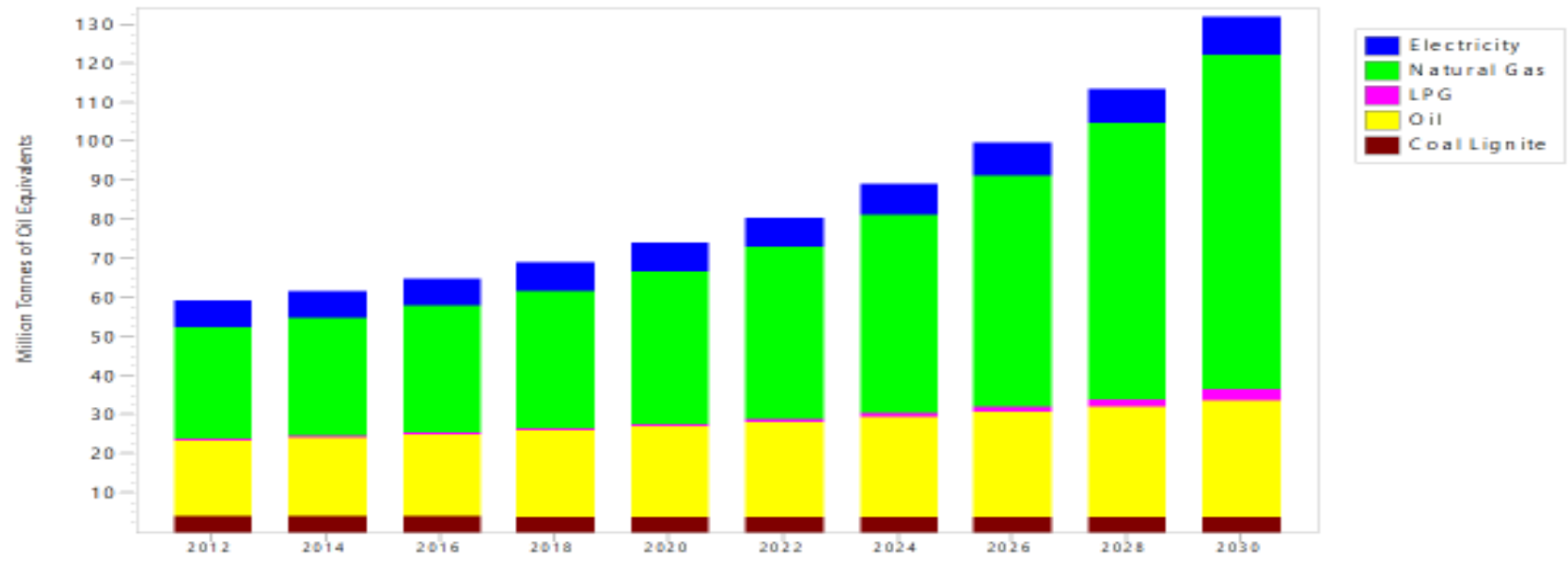

Figure 3: Fuel demand forecast 


\section{All Capacitities}

Business As Usual Scenario

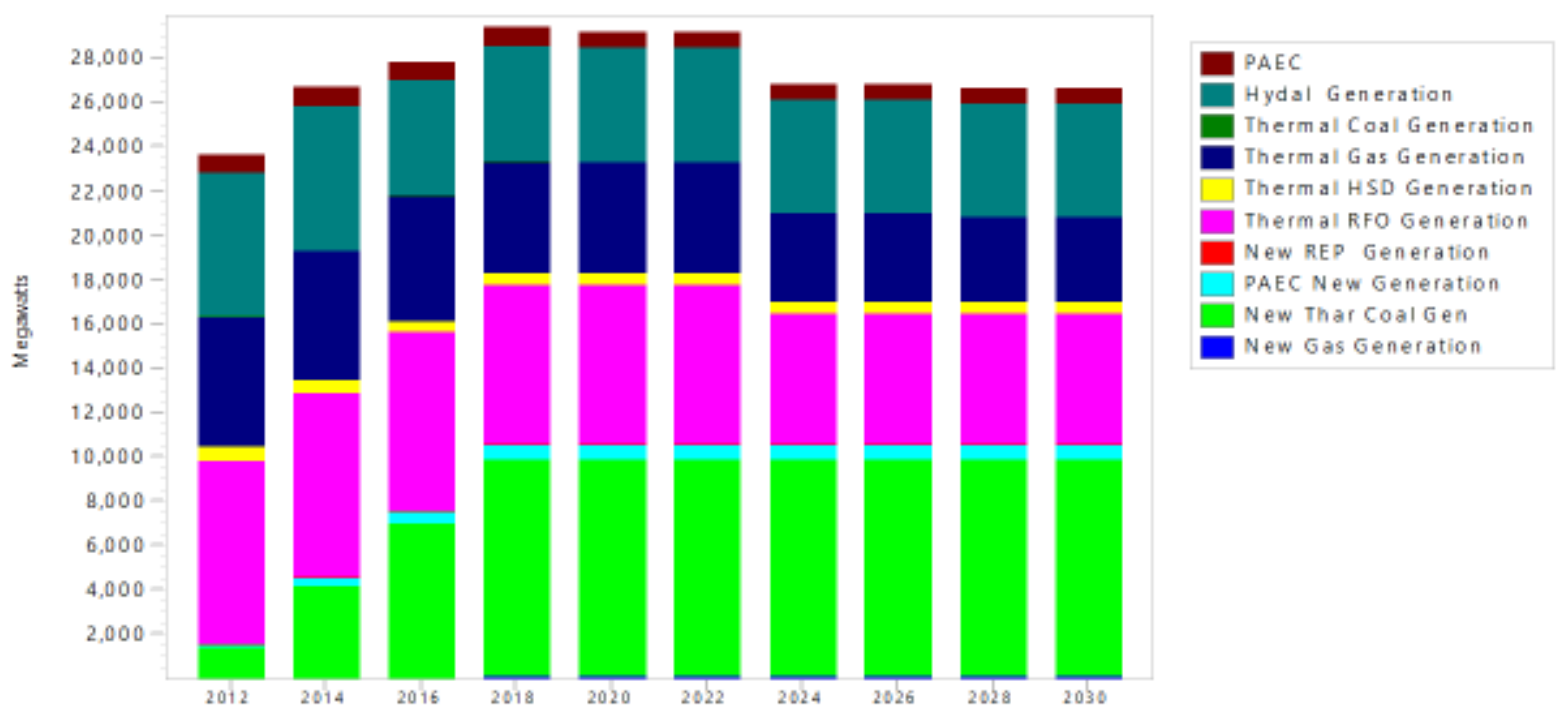

Figure 4: Capacity installed in BAU Scenario

\section{All Capacities}

Green Pakistan Scenario

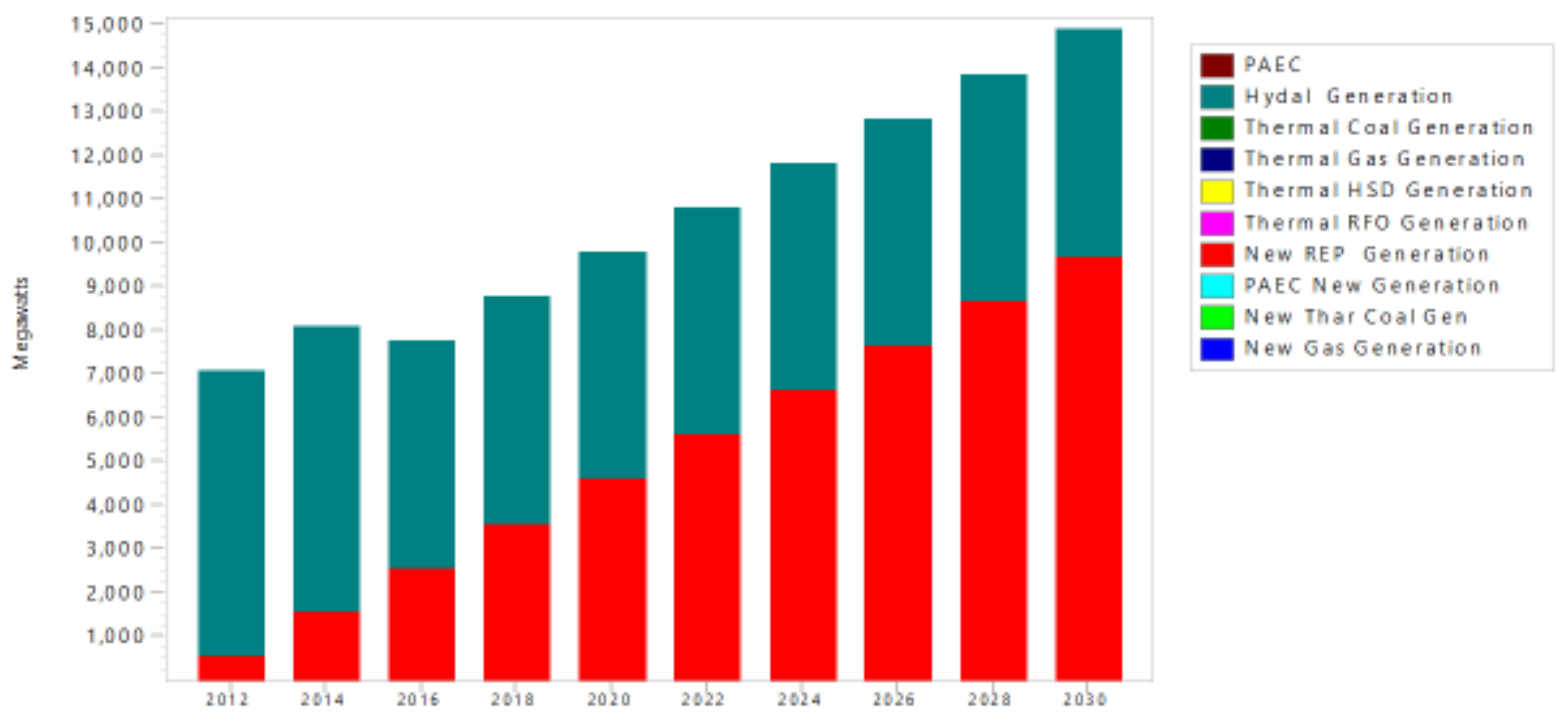

Figure 5: Capacity installed in GP Scenario 


\section{All Capacities}

Nuclear Scenario

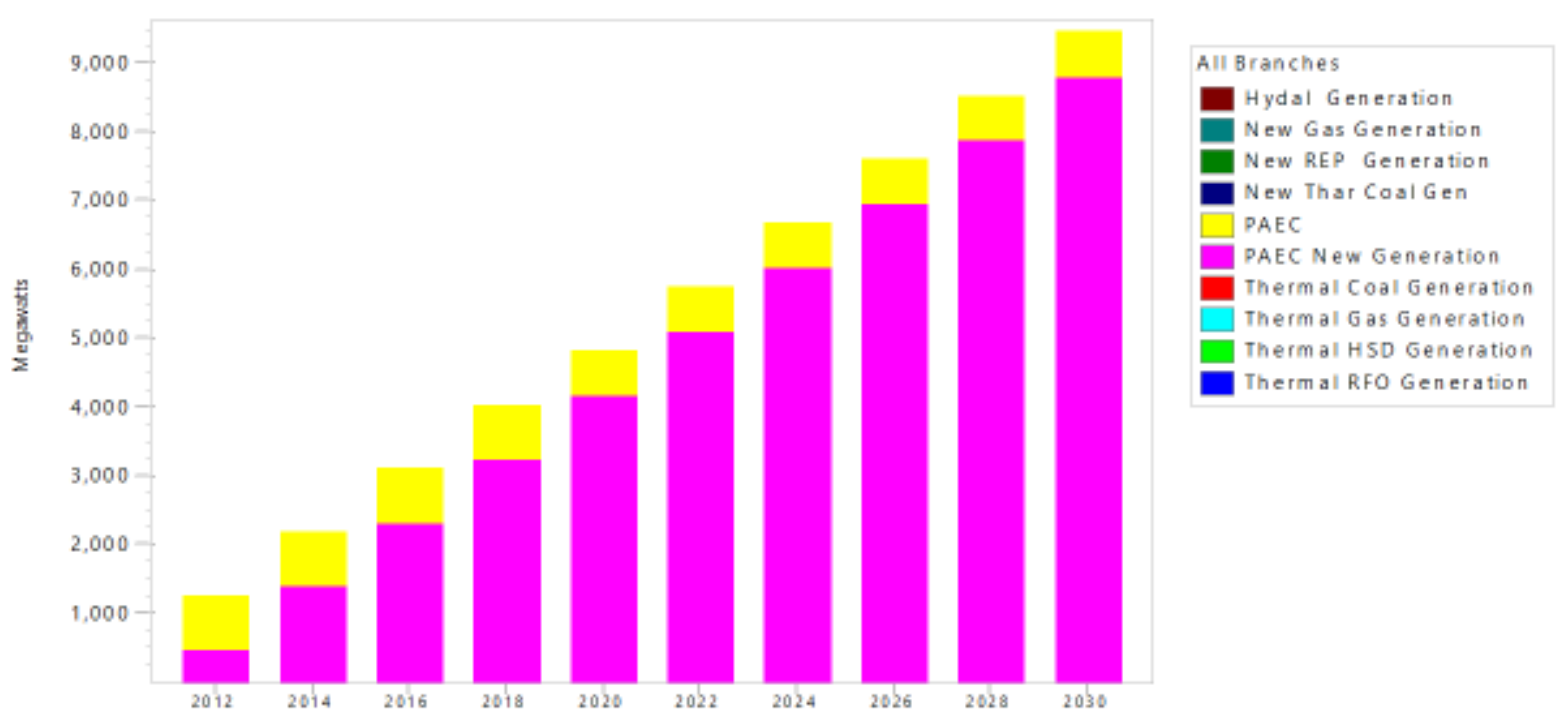

Figure 6: Capacity installed in Nuclear Scenario

\section{All Capacities}

\section{OPTIMIZATION Scenario}

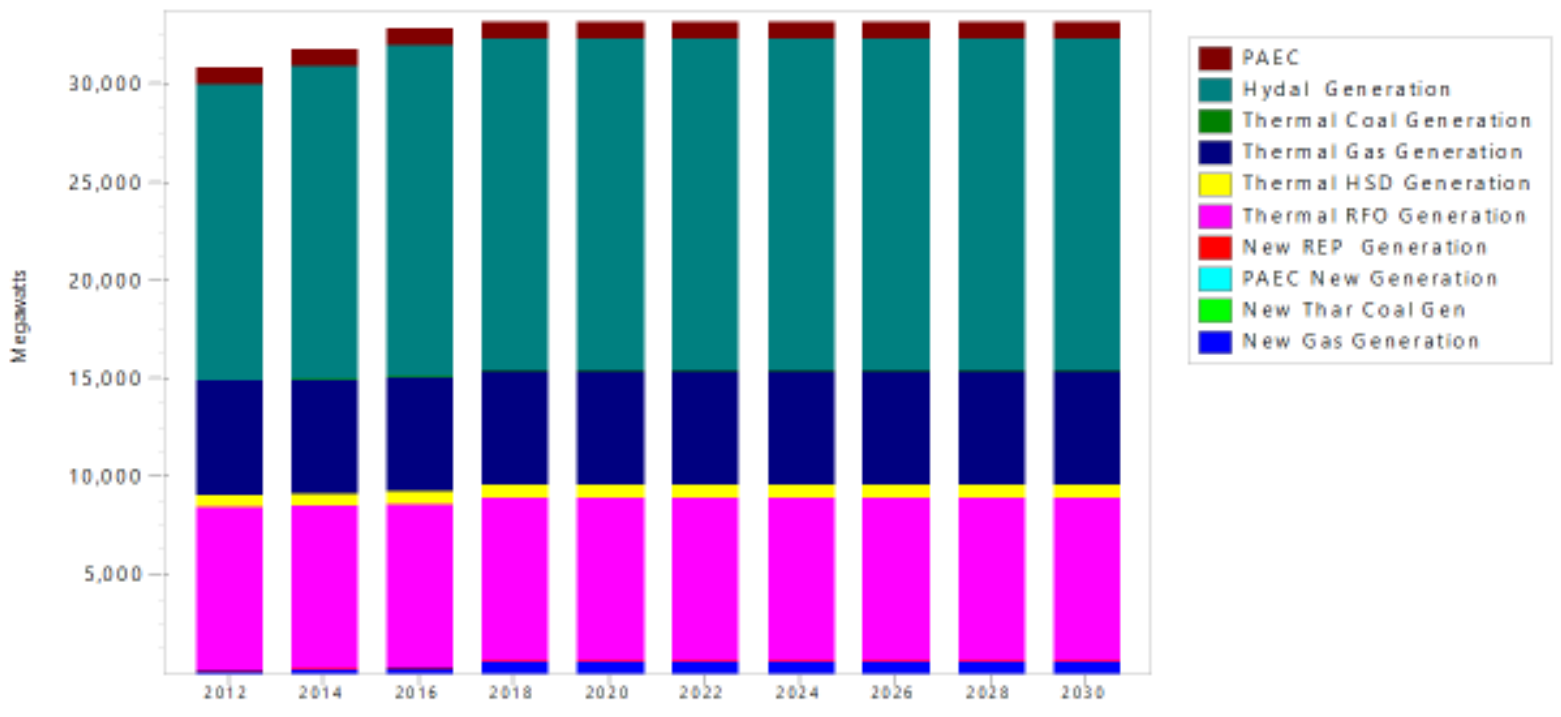

Figure 7: Capacity installed in Optimization Scenario 
Generated Electricity in MTOE

Business As Usual Scenario

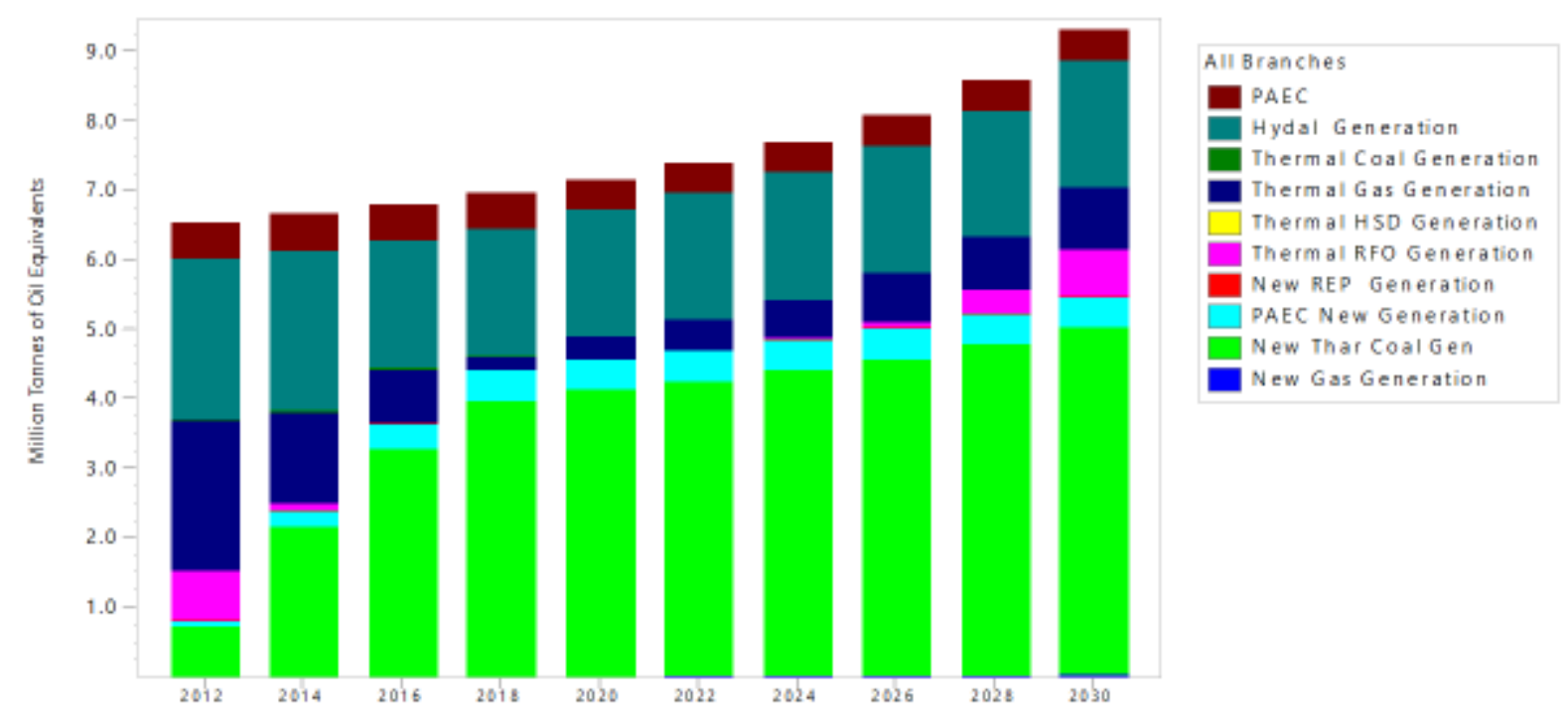

Figure 8: Electricity generated in BAU Scenario

Generated Electricity in MTOE

Green Pakistan Scenario

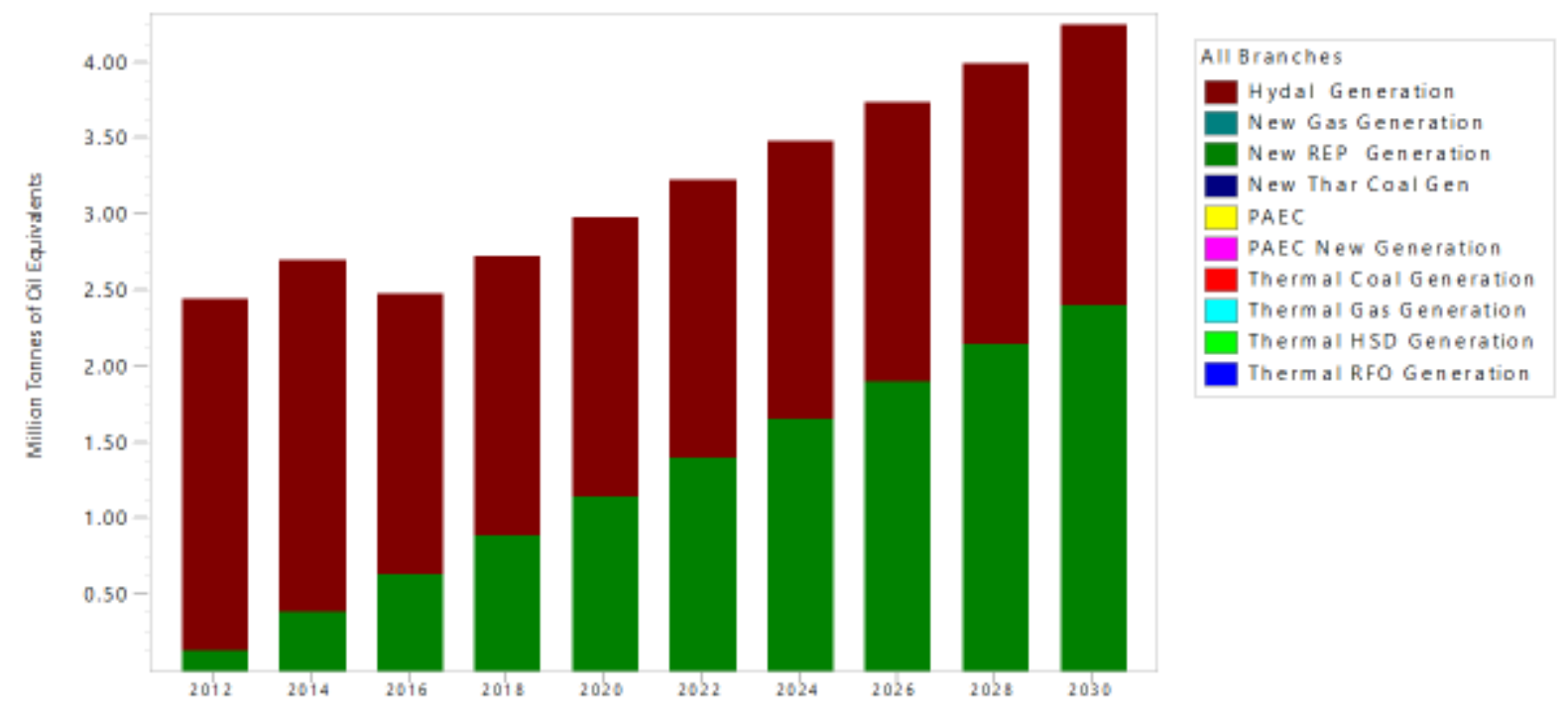

Figure 9: Electricity generated in Green Pakistan Scenario 
Generated Electricity in MTOE

Nuclear Scenario

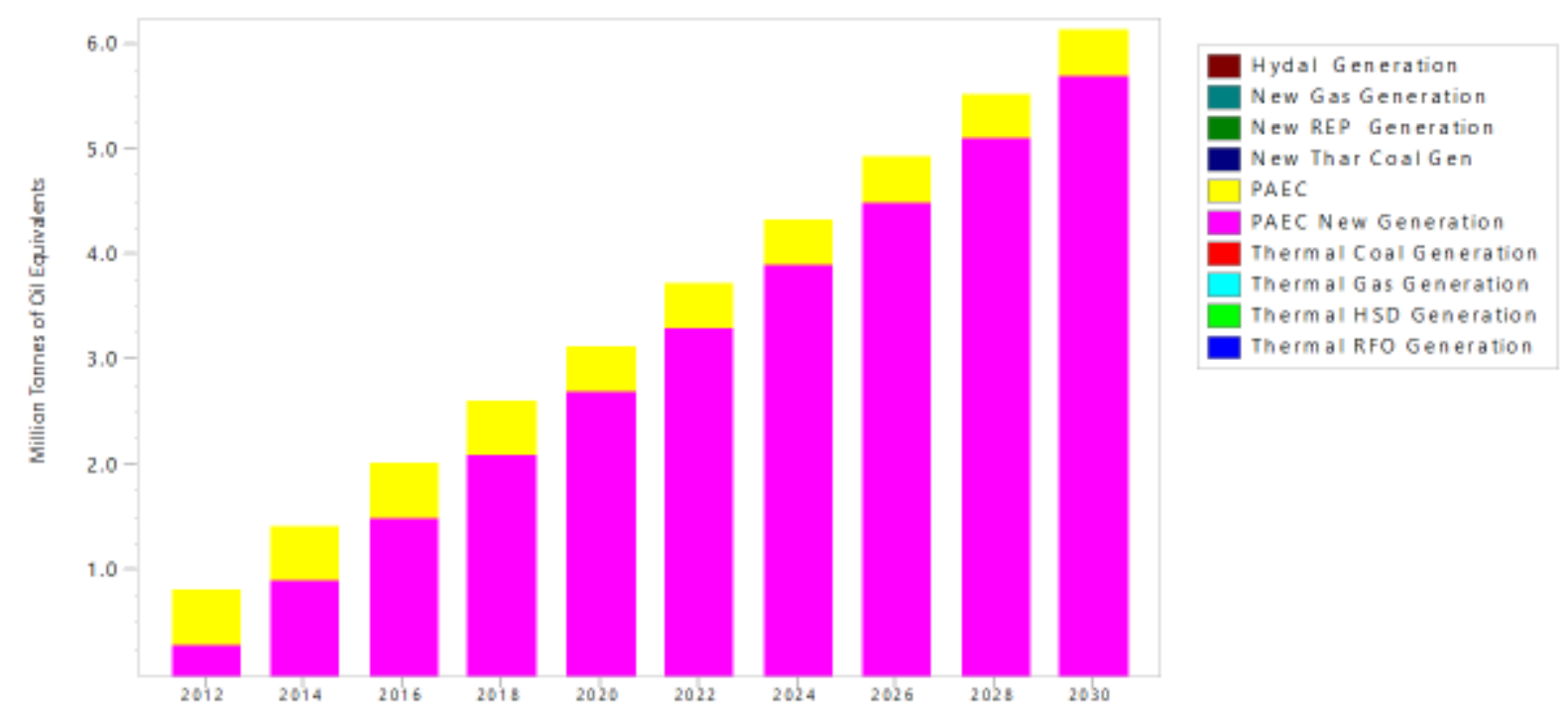

Figure 10: Electricity generated in Nuclear Scenario

Generated Electricity in MTOE

OPTIMIZATION Scenario

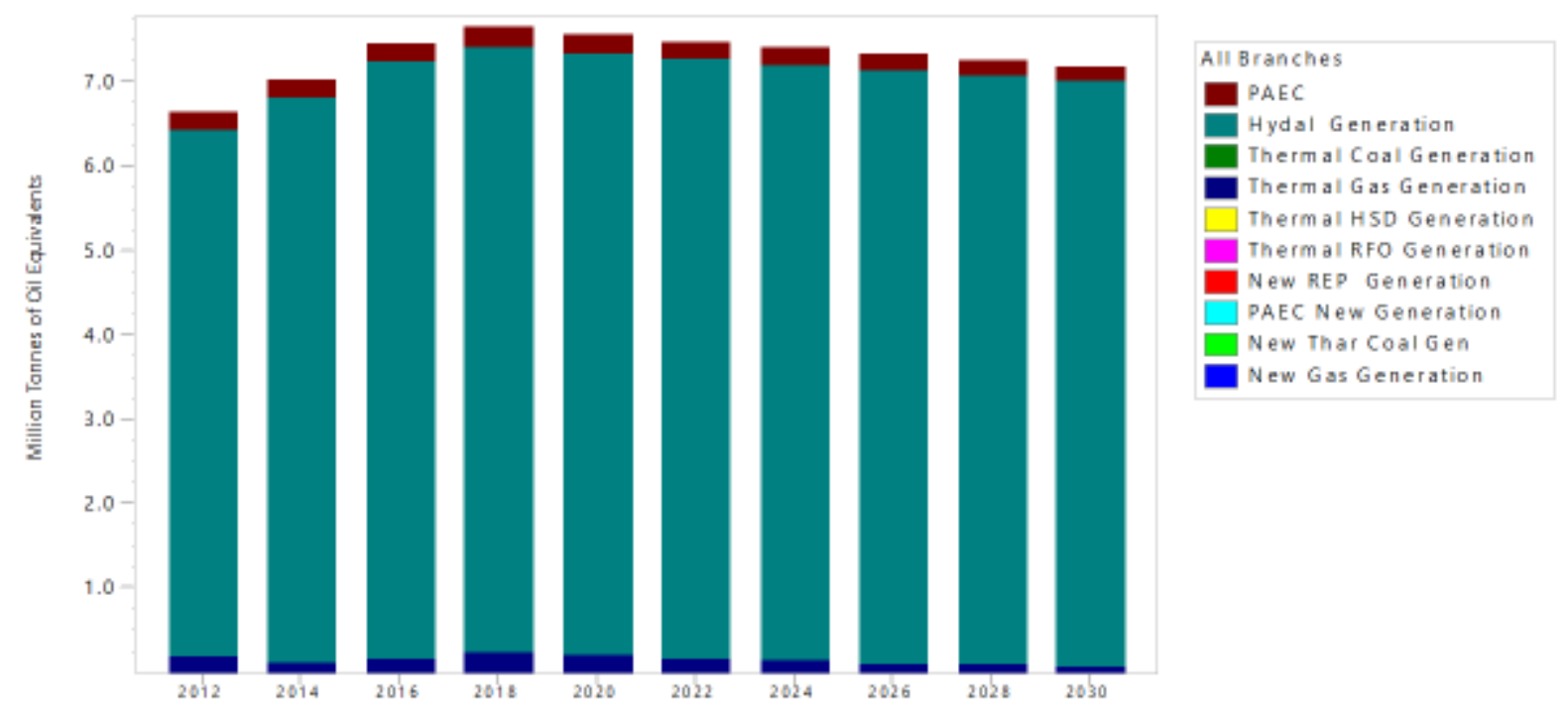

Figure 11: Electricity generated in Optimization Scenario. 


\section{Cost of Production}

Business As Usual Scenario

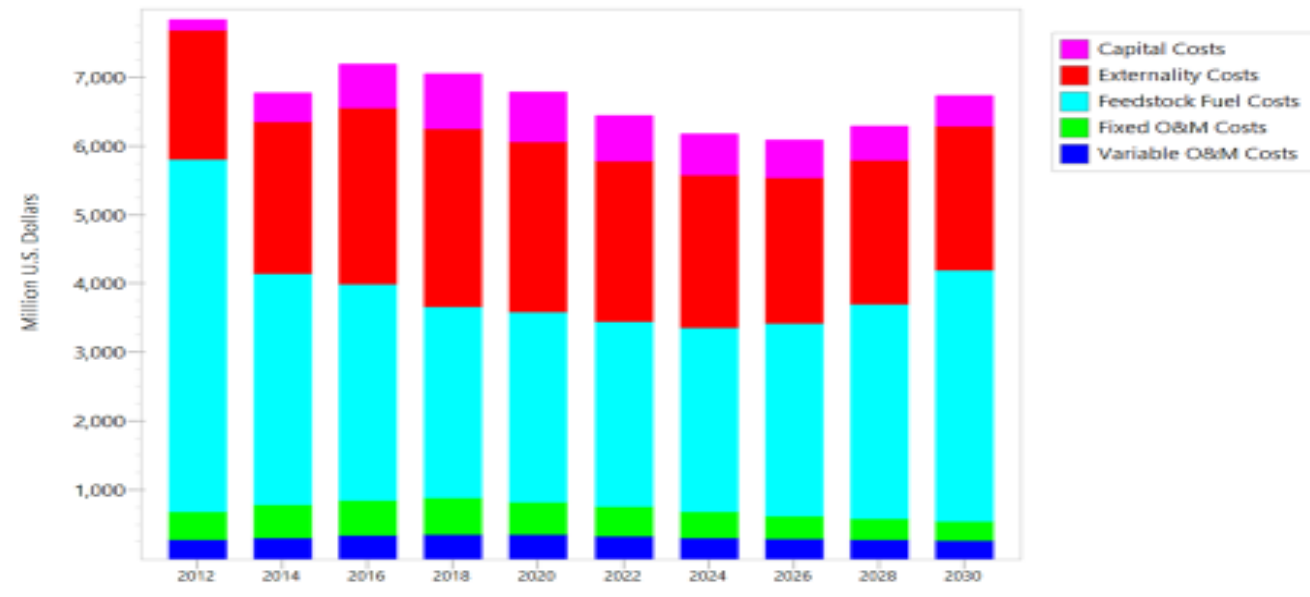

Figure 12: Electricity generation costs in BAU Scenario.

\section{Cost of Production}

Green Pakistan Scenario

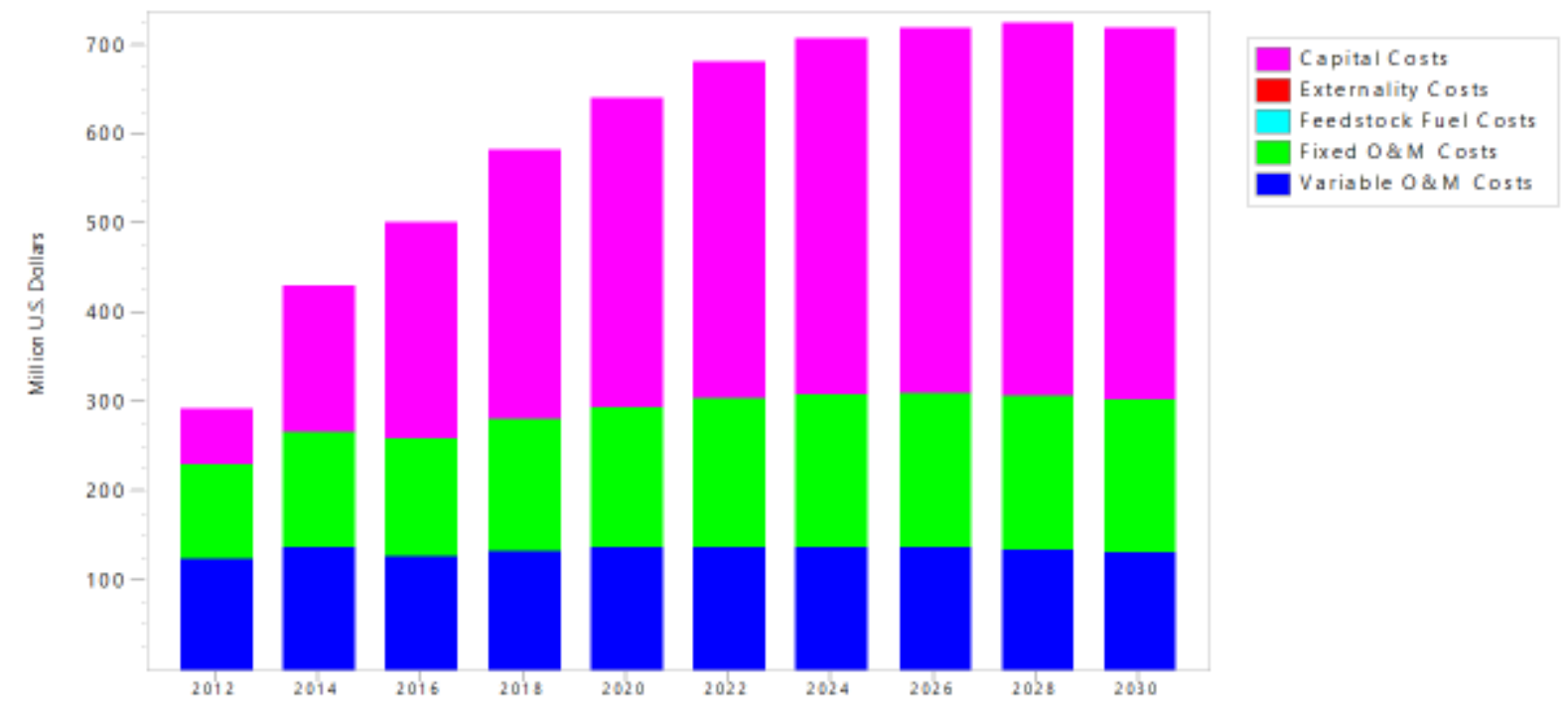

Figure 13: Electricity generation costs in Green Pakistan Scenario. 


\section{Cost of Production}

Nuclear Scenario

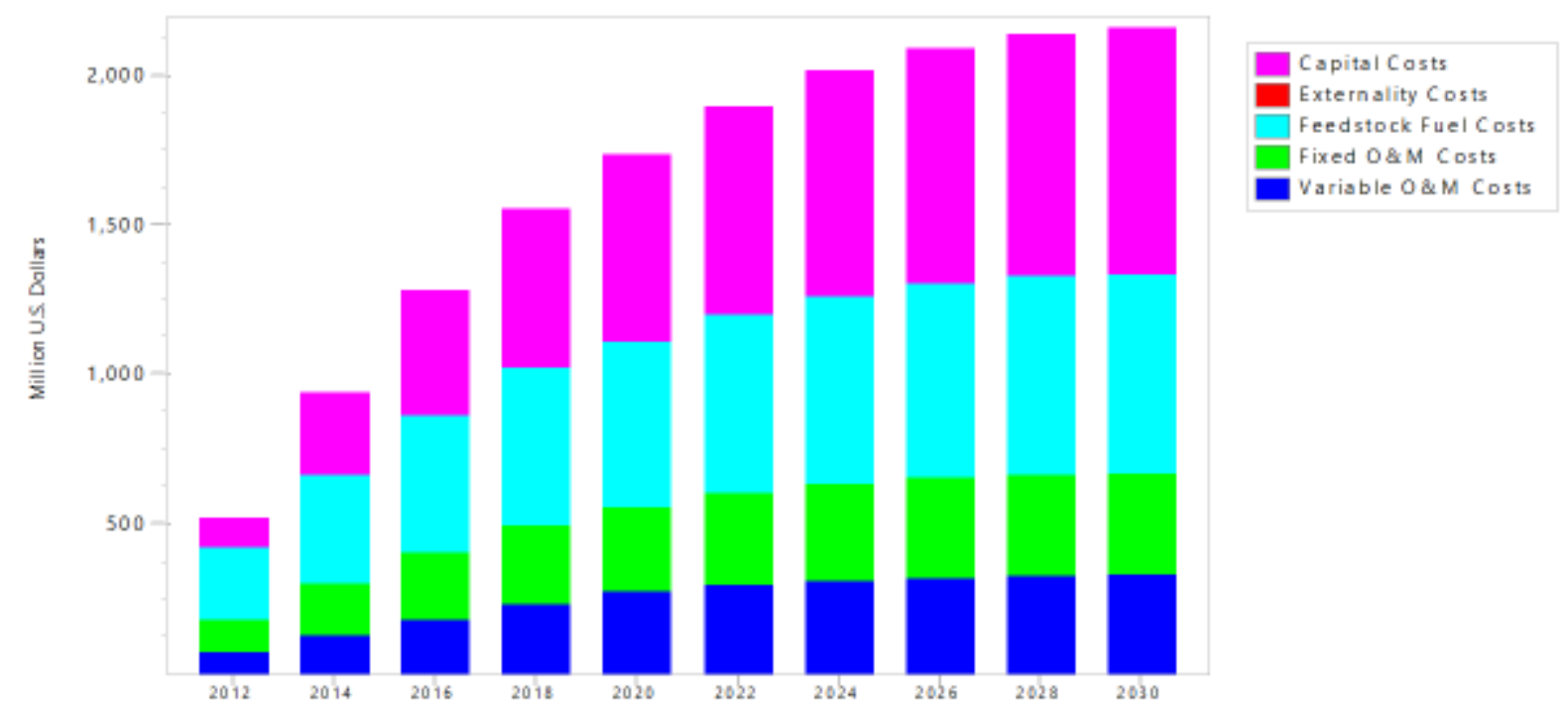

Figure 14: Electricity generation costs in nuclear scenario.

\section{Cost of Production}

OPTIMIZATION Scenario

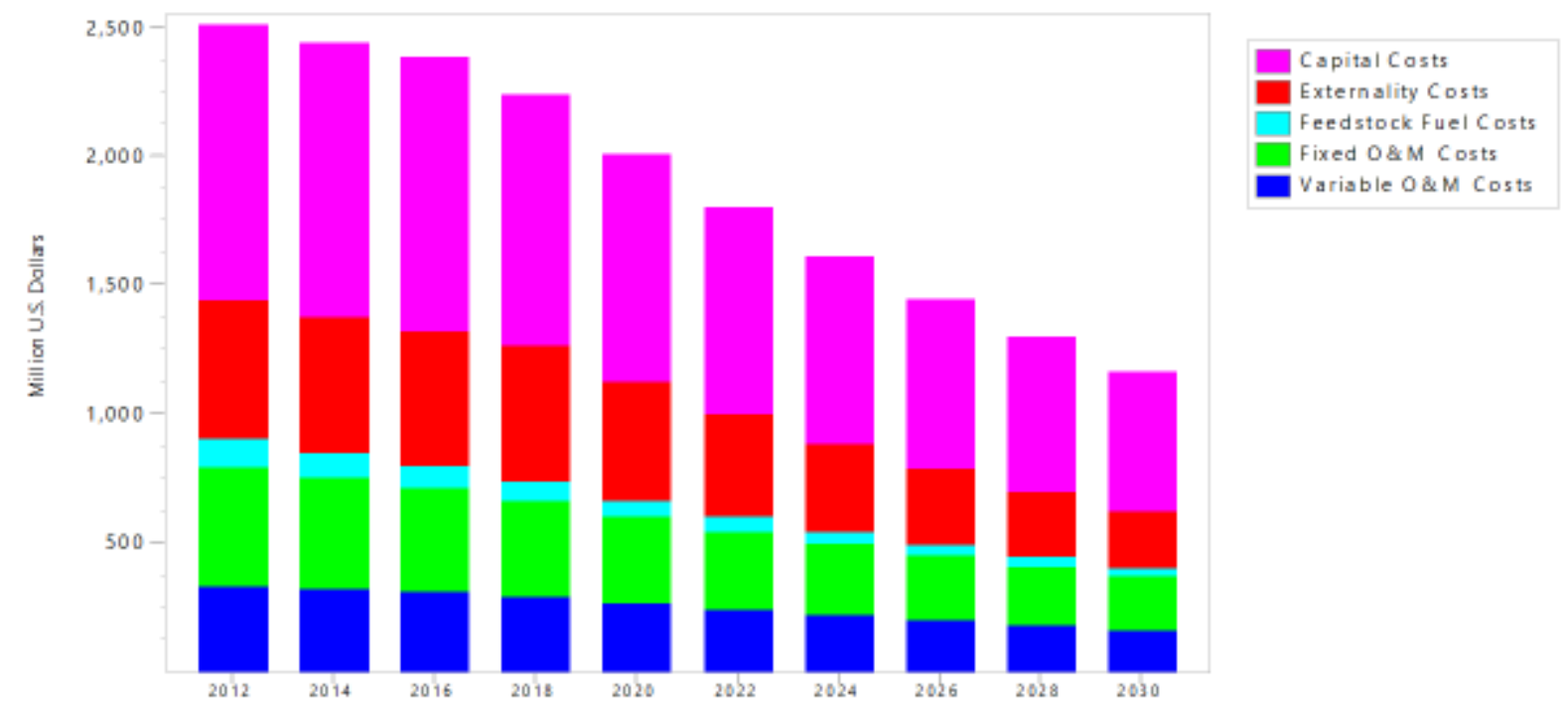

Figure 15: Electricity generation costs in Optimization scenario. 
One Hundred Year GWP: Direct (At Point of Emissions)

Electricity generated in Business As Usual Scenario, All Fuels, All GHGs

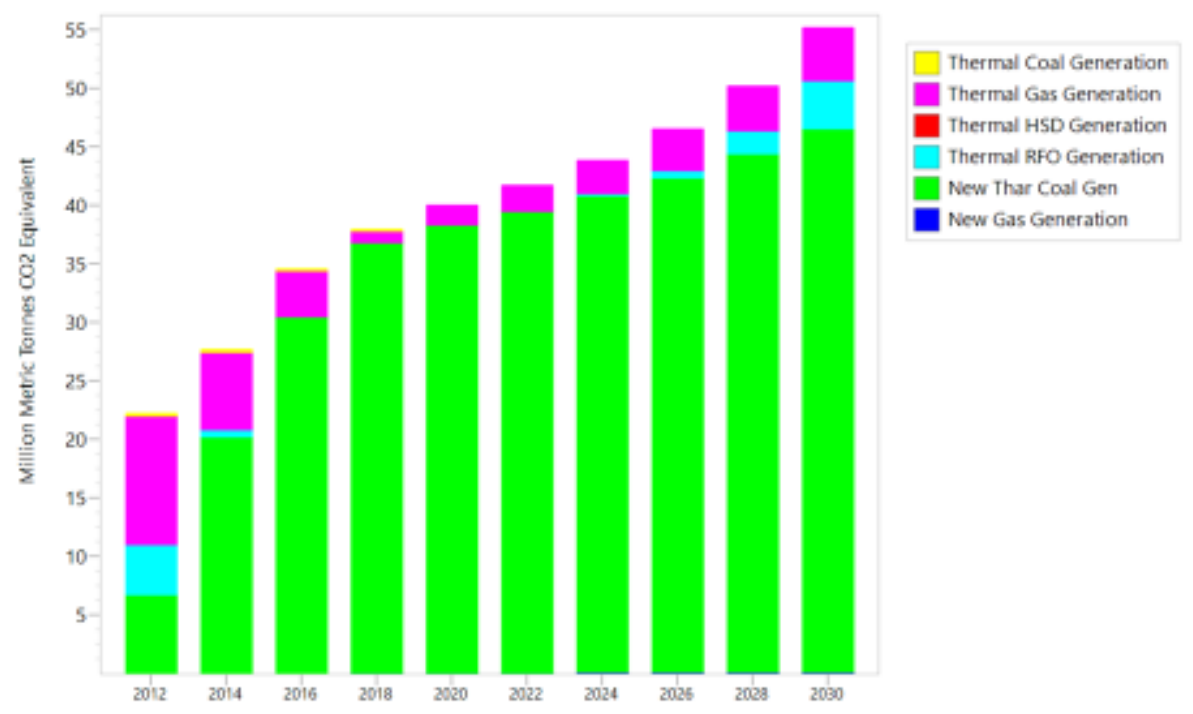

Figure 16: One-hundred-year global warming potential due to generated electricity in BAU scenario.

\section{Supply Forecast}

Coal, natural gas, LPG and Refined oil

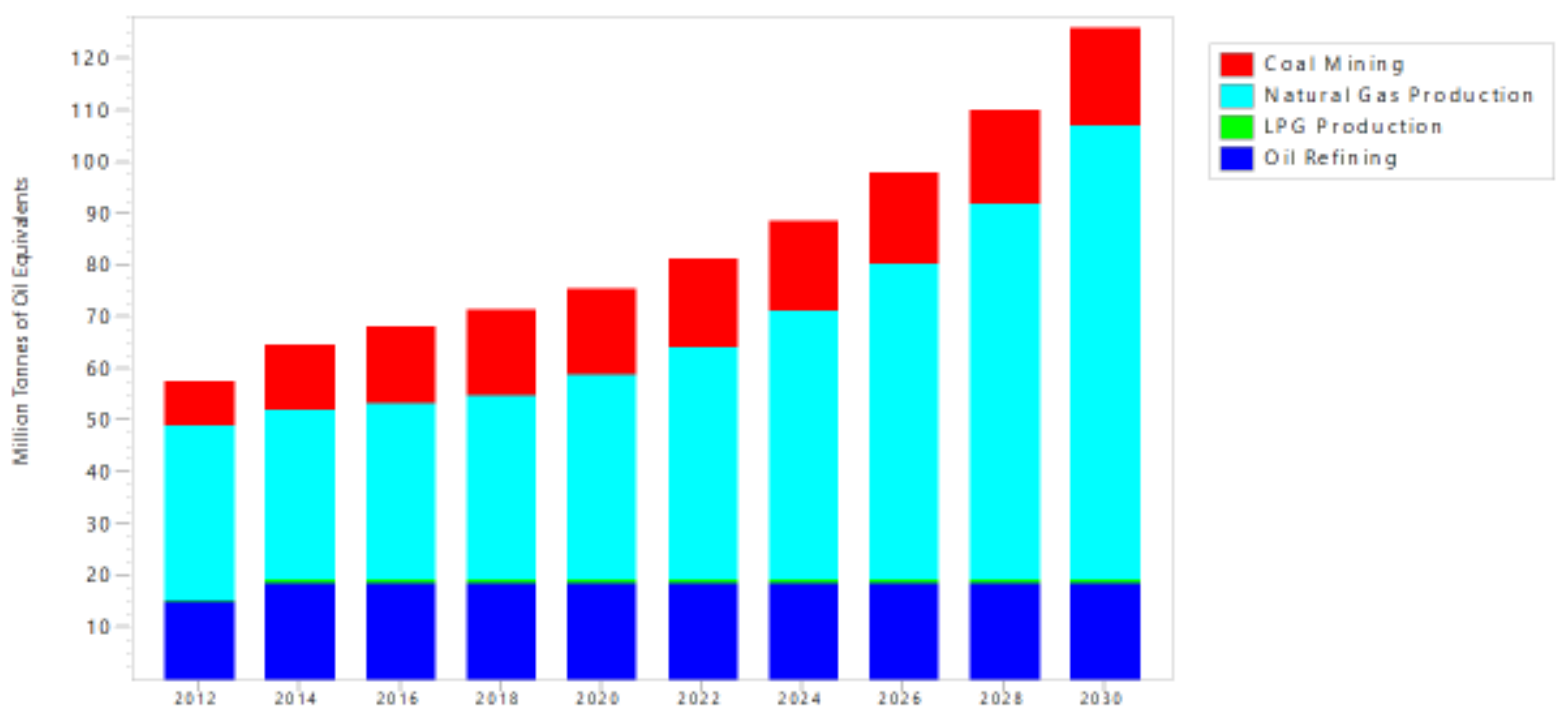

Figure 17: Supply forecast of coal, natural gas, LPG and refined oil in MTOE. 
Table 1: Fuels consumption (MTOE) and Annual compound growth rate (percent) in base year (2011-12).

\begin{tabular}{|c|c|c|c|c|c|c|c|c|c|c|c|}
\hline Fuels & & il & Nat & al Gas & Ele & ricity & & & & oal & Overall \\
\hline Sectors & \begin{tabular}{|l} 
Cons \\
\end{tabular} & $\begin{array}{l}\mathrm{ACG} \\
\mathrm{R}\end{array}$ & $\begin{array}{l}\text { Con } \\
\text { s. }\end{array}$ & $\begin{array}{l}\mathrm{ACG} \\
\mathrm{R}\end{array}$ & $\begin{array}{l}\text { Con } \\
\text { s. }\end{array}$ & $\begin{array}{l}\text { ACG } \\
\mathrm{R}\end{array}$ & Cons. & $\begin{array}{l}\mathrm{ACG} \\
\mathrm{R}\end{array}$ & $\begin{array}{l}\text { Con } \\
\text { s. }\end{array}$ & $\begin{array}{l}\mathrm{ACG} \\
\mathrm{R}\end{array}$ & $\begin{array}{l}\text { Sector } \\
\text { ACGR }\end{array}$ \\
\hline Domestic & $\begin{array}{l}0.08 \\
2\end{array}$ & -5.6 & $\begin{array}{l}6.12 \\
9\end{array}$ & 7.1 & $\begin{array}{l}2.89 \\
8\end{array}$ & 1.3 & 0.251 & -10.5 & & & 4.2 \\
\hline Industry & $\begin{array}{l}1.42 \\
3 \\
\end{array}$ & -2.6 & $\begin{array}{l}7.77 \\
8\end{array}$ & -1.3 & $\begin{array}{l}1.77 \\
6 \\
\end{array}$ & 0.7 & & & $\begin{array}{l}4.05 \\
7\end{array}$ & -0.4 & -1 \\
\hline Agriculture & $\begin{array}{l}0.02 \\
4 \\
\end{array}$ & -24.9 & & & $\begin{array}{l}0.69 \\
6 \\
\end{array}$ & 0.9 & & & & & -1.3 \\
\hline $\begin{array}{l}\text { Commercia } \\
1\end{array}$ & & & $\begin{array}{l}0.92 \\
7 \\
\end{array}$ & 4.8 & \begin{tabular}{|l|}
0.46 \\
9 \\
\end{tabular} & 1.4 & 0.190 & -1.7 & & & 2.9 \\
\hline Others & \begin{tabular}{|l|}
0.31 \\
0 \\
\end{tabular} & -1.9 & & & $\begin{array}{l}0.41 \\
3 \\
\end{array}$ & 1.3 & 0.040 & 25.3 & & & 0.6 \\
\hline TPG & \begin{tabular}{|l|}
7.41 \\
0 \\
\end{tabular} & 2.4 & $\begin{array}{l}6.73 \\
3 \\
\end{array}$ & -4.9 & & & & & $\begin{array}{l}0.04 \\
68 \\
\end{array}$ & -8.6 & -1.5 \\
\hline Fertilizers & & & $\begin{array}{l}3.97 \\
4\end{array}$ & 1.00 & & & & & & & 1 \\
\hline Transport & 9.78 & 3.0 & $\begin{array}{l}2.78 \\
5\end{array}$ & 16.1 & $\begin{array}{l}0.00 \\
008 \\
1\end{array}$ & -39.1 & & & & & \\
\hline
\end{tabular}

Legend: Cons.: Consumption, ACGR: Annual compound growth rate

Table 2: Electricity Supplied during 2011-2012 in GWh.

\begin{tabular}{|c|c|c|c|c|c|c|c|c|}
\hline Source & \multicolumn{4}{|c|}{ Thermal } & Hydel & Nuclea & Renewables & Total \\
\hline \multirow[t]{2}{*}{ Supply } & $\begin{array}{l}\text { Natural } \\
\text { gas }\end{array}$ & $\begin{array}{l}\text { Furnace } \\
\text { Oil }\end{array}$ & Diesel & Coal & \multirow{2}{*}{$\begin{array}{c}28466 . \\
2\end{array}$} & \multirow{2}{*}{4872} & \multirow{2}{*}{50.7} & \multirow[t]{2}{*}{$94,697.3$} \\
\hline & 27650.2 & 33206.5 & 355.7 & 96 & & & & \\
\hline $\begin{array}{l}\text { Percent of total } \\
(\%)\end{array}$ & 29.20 & 35.06 & 0.3 & 0.1 & 30 & 5.1 & .05 & 99.81 \\
\hline
\end{tabular}


Table 3: Coal mines and properties

\begin{tabular}{|c|c|c|c|c|c|c|c|}
\hline & $\begin{array}{l}\text { Moisture } \\
\%\end{array}$ & $\begin{array}{l}\text { Volatile } \\
\text { Matter \% }\end{array}$ & $\begin{array}{l}\text { Fixed } \\
\text { Carbon } \%\end{array}$ & $\begin{array}{l}\text { Ash } \\
\text { Content \% }\end{array}$ & $\begin{array}{l}\text { Total } \\
\text { Sulfur \% }\end{array}$ & $\begin{array}{l}\text { Heating } \\
\text { Value } \\
(\mathrm{Btu} / \mathrm{lb})\end{array}$ & $\begin{array}{l}\text { Seam } \\
\text { thickness } \\
\text { in meters }\end{array}$ \\
\hline $\begin{array}{l}\text { Barkhan- } \\
\text { Chamala }\end{array}$ & $1.1-2.9$ & $24.9-43.5$ & $19.4-47.1$ & $9.1-36.5$ & $3.0-8.5$ & $\begin{array}{l}12500- \\
14357\end{array}$ & $0.3-2$ \\
\hline Duki & $3.5-11.5$ & $32-50$ & $28-42$ & $5-38$ & $4-6$ & $\begin{array}{l}10131- \\
14164\end{array}$ & $0.2-2.3$ \\
\hline Mach & $7.1-12$ & $34.2-43$ & $32.4-41.5$ & $9.6-20.3$ & $3.2-7.4$ & $\begin{array}{l}11110- \\
12937\end{array}$ & $0.6-1.3$ \\
\hline Degari & $3.9-18.9$ & $20.7-37.5$ & $41-50.8$ & $4.9-17.2$ & $0.6-5.5$ & $\begin{array}{l}11245- \\
13000\end{array}$ & $0.3-1.3$ \\
\hline Ziarat & $6.3-13.2$ & $34.6-41$ & $19.3-42.5$ & $10.3-37.5$ & $3.2-7.4$ & $\begin{array}{l}10787- \\
11996\end{array}$ & $0.4-0.7$ \\
\hline Harnai & $1.7-11.2$ & $9.3-45.3$ & $25.5-43.8$ & $9.3-34$ & $3.5-9.55$ & $\begin{array}{l}9637- \\
15499\end{array}$ & $0.3-2.3$ \\
\hline Makarwal & $2.8-6$ & $31.5-48.1$ & $34.9-44.9$ & $6.4-30.8$ & $2.8-6.3$ & $\begin{array}{l}10688- \\
14029\end{array}$ & $0.3-2$ \\
\hline Salt Range & $3.2-10.8$ & $21.5-38.8$ & $25.7-44.8$ & $12.3-44.2$ & $2.6-10.7$ & $\begin{array}{l}9472- \\
15801\end{array}$ & $0.15-1.2$ \\
\hline Lakhra & $9.7-38.1$ & $18.3-38.6$ & $9.8-38.2$ & $4.3-49$ & $1.2-14.8$ & $\begin{array}{l}5503- \\
9158 \\
\end{array}$ & $0.3-33$ \\
\hline Sonda & $22.6-48$ & $16.1-36.9$ & $8.9-31.6$ & $2.7-52$ & $0.2-15$ & $\begin{array}{l}8878- \\
13555\end{array}$ & $0.3-1.5$ \\
\hline Jherruck & $9-39.5$ & $20-44.2$ & $15-58.8$ & $5-39$ & $0.4-7.7$ & $\begin{array}{l}8800- \\
12846\end{array}$ & $0.3-6.2$ \\
\hline Ongar & $9-39.5$ & $20-44.2$ & $15-58.8$ & $5-39$ & $0.4-7.7$ & $\begin{array}{l}5219- \\
11172\end{array}$ & $0.3-1.5$ \\
\hline Indus East & $9-39.5$ & $20-44.2$ & $15-58.8$ & $5-39$ & $0.4-7.7$ & $\begin{array}{l}7782- \\
8660\end{array}$ & $0.3-2.5$ \\
\hline Jhimpir & $26.6-36.6$ & $25.2-34$ & $24.1-32.2$ & $8.2-16.8$ & $2.9-5.1$ & $\begin{array}{l}7734- \\
8612\end{array}$ & $0.3-1$ \\
\hline Badin & N.A & N.A & N.A & N.A & N.A & $\begin{array}{l}11415- \\
11521\end{array}$ & $0.55-3.1$ \\
\hline Thar Coal & $29.6-55.5$ & $23.1-36.6$ & $14.25-34$ & $2.9-11.5$ & $0.4-2.9$ & $\begin{array}{l}6244- \\
1104 \\
\end{array}$ & $\begin{array}{l}0.2- \\
22.81 \\
\end{array}$ \\
\hline Hangu & $0.2-2.5$ & $16.2-33.4$ & $21.8-49.8$ & $5.3-43.3$ & $1.5-9.5$ & $\begin{array}{l}10500- \\
14149\end{array}$ & $0.43-0.6$ \\
\hline Chirat & $0.1-7.1$ & $14.0-31.2$ & $37.0-76.9$ & $6.1-39.0$ & $1.1-3.5$ & $\begin{array}{l}9386- \\
14171\end{array}$ & $0.8-1.2$ \\
\hline Kotli & $0.2-6.0$ & $5.1-32.0$ & $26.3-69.5$ & $3.3-50.0$ & $0.3-4.8$ & $\begin{array}{l}7336- \\
12338\end{array}$ & $0.25-1$ \\
\hline
\end{tabular}

Source: Pakistan Energy Year Book 2012 [41]. 
Table 4: Natural gas supply priority chart

\begin{tabular}{|c|c|}
\hline Category of Consumer & Priority \\
\hline $\begin{array}{ll}\text { Domestic } & \text { and } \\
\text { Commercial } & \end{array}$ & $\mathbf{1}$ \\
\hline Power & 2 \\
\hline $\begin{array}{l}\text { Industrial/ } \\
\text { power }\end{array}$ & 3 \\
\hline $\begin{array}{l}\text { Cement \& its Captive } \\
\text { Power }\end{array}$ & 4 \\
\hline $\mathrm{CNG}$ & 5 \\
\hline
\end{tabular}

Table 5: Energy supply forecast.

\begin{tabular}{|l|l|l|}
\hline Process Name & $\begin{array}{l}\text { Capacity } \\
\text { Projection }\end{array}$ & $\begin{array}{l}\text { Production } \\
\text { Projection }\end{array}$ \\
\hline All Mines & 3450 MTCE & ACGR (-0.2\%) \\
\hline All imports & 4.057 MTCE & ACGR (-0.9\%) \\
\hline All Refining & Interp(2014,18.79) & ACGR (-4\%) \\
\hline NG Production & 488.19 MTOE & ACGR (2\%) \\
\hline LPG imports & Growth rate (1\%) & ACGR (4.1\%) \\
\hline LPG Refineries & Growth rate (1\%) & ACGR (-4.4\%) \\
\hline LPG Field & Growth rate (1\%) & $\begin{array}{l}\text { ACGR } \\
\text { Plants }\end{array}$ \\
\hline
\end{tabular}


Table 6: Energy and non-energy demand forecast of Pakistan in MTOE.

\begin{tabular}{|c|c|c|c|c|c|c|c|c|c|c|}
\hline Years & $\begin{array}{l}2012 \\
\text { MTOE }\end{array}$ & $\begin{array}{l}2014 \\
\text { MTOE }\end{array}$ & $\begin{array}{l}2016 \\
\text { MTOE }\end{array}$ & $\begin{array}{l}2018 \\
\text { MTOE }\end{array}$ & $\begin{array}{l}2020 \\
\text { MTOE }\end{array}$ & $\begin{array}{l}2022 \\
\text { MTOE }\end{array}$ & $\begin{array}{l}2024 \\
\text { MTOE }\end{array}$ & $\begin{array}{l}2026 \\
\text { MTOE }\end{array}$ & $\begin{array}{l}2028 \\
\text { MTOE }\end{array}$ & $\begin{array}{l}2030 \\
\text { MTOE }\end{array}$ \\
\hline Household & 9.8 & 10.8 & 11.9 & 13.2 & 14.8 & 16.5 & 18.5 & 20.7 & 23.3 & 26.3 \\
\hline Industry & 14.9 & 14.6 & 14.3 & 14.1 & 13.8 & 13.6 & 13.4 & 13.1 & 12.9 & 12.7 \\
\hline Transport & 13.3 & 15.0 & 17.2 & 19.9 & 23.4 & 27.9 & 33.8 & 41.4 & 51.4 & 64.6 \\
\hline Agriculture & 0.7 & 0.7 & 0.7 & 0.7 & 0.8 & 0.8 & 0.8 & 0.8 & 0.8 & 0.8 \\
\hline Commercial & 1.6 & 1.7 & 1.8 & 2.0 & 2.1 & 2.3 & 2.4 & 2.6 & 2.8 & 3.0 \\
\hline Others & 0.8 & 0.8 & 0.8 & 0.9 & 1.0 & 1.2 & 1.5 & 1.9 & 2.6 & 3.7 \\
\hline TPG & 14.0 & 13.7 & 13.6 & 13.5 & 13.5 & 13.5 & 13.6 & 13.7 & 14.0 & 14.2 \\
\hline Fertilizers & 4.0 & 4.1 & 4.2 & 4.3 & 4.4 & 4.5 & 4.5 & 4.6 & 4.7 & 4.8 \\
\hline Auxiliary & 0.2 & 0.2 & 0.2 & 0.2 & 0.3 & 0.3 & 0.5 & 0.7 & 1.0 & 1.6 \\
\hline Total & 59.3 & 61.7 & 64.9 & 68.9 & 74.0 & 80.5 & 88.9 & 99.7 & 113.6 & 131.8 \\
\hline Electricity & 6.5 & 6.6 & 6.8 & 7.0 & 7.1 & 7.4 & 7.7 & 8.1 & 8.6 & 9.3 \\
\hline Natural Gas & 28.9 & 30.3 & 32.4 & 35.2 & 39.0 & 44.0 & 50.7 & 59.4 & 70.8 & 85.8 \\
\hline LPG & 0.5 & 0.4 & 0.4 & 0.5 & 0.6 & 0.7 & 1.0 & 1.4 & 2.0 & 3.1 \\
\hline Oil & 19.4 & 20.3 & 21.3 & 22.3 & 23.4 & 24.5 & 25.7 & 27.0 & 28.4 & 29.9 \\
\hline Coal & 4.0 & 4.0 & 4.0 & 3.9 & 3.9 & 3.9 & 3.9 & 3.8 & 3.8 & 3.8 \\
\hline
\end{tabular}

Pakistan's demand forecast including energy and non-energy demand of fertilizers.

TPG: Thermal Power Generation 
Table 7: Capacity and output of four Scenarios

\begin{tabular}{|l|l|l|l|l|l|l|l|l|}
\hline Years & $\begin{array}{l}\text { BAU } \\
\text { Capacity } \\
\text { Thousand } \\
\text { MW }\end{array}$ & $\begin{array}{l}\text { BAU } \\
\text { Output in } \\
\text { MTOE }\end{array}$ & $\begin{array}{l}\text { GP } \\
\text { Capacity } \\
\text { Thousand } \\
\text { MW }\end{array}$ & $\begin{array}{l}\text { GP Output } \\
\text { In MTOE }\end{array}$ & $\begin{array}{l}\text { NS } \\
\text { Capacity } \\
\text { Thousand } \\
\text { MW }\end{array}$ & $\begin{array}{l}\text { NS } \\
\text { Output in } \\
\text { MTOE }\end{array}$ & $\begin{array}{l}\text { Optimization } \\
\text { Capacity } \\
\text { Thousand } \\
\text { MW }\end{array}$ & $\begin{array}{l}\text { Optimization } \\
\text { Output in } \\
\text { MTOE }\end{array}$ \\
\hline 2012 & 23.7 & $\mathbf{6 . 5}$ & 7.1 & 2.4 & 1.3 & 0.8 & 35.3 & 6.6 \\
\hline 2014 & 26.7 & $\mathbf{6 . 7}$ & 8.1 & 2.7 & 2.2 & 1.4 & 37.3 & 7.0 \\
\hline 2016 & 27.7 & $\mathbf{6 . 8}$ & 7.8 & 2.5 & 3.1 & 2.0 & 38.4 & 7.5 \\
\hline 2018 & 29.4 & $\mathbf{7 . 0}$ & 8.8 & 2.7 & 4.0 & 2.6 & 38.4 & 7.6 \\
\hline 2020 & 29.2 & $\mathbf{7 . 2}$ & 9.8 & 3.0 & 4.8 & 3.1 & 38.4 & 7.6 \\
\hline 2022 & 29.2 & $\mathbf{7 . 4}$ & 10.8 & 3.2 & 5.7 & 3.7 & 38.4 & 7.5 \\
\hline 2024 & 26.8 & $\mathbf{7 . 7}$ & 11.8 & 3.5 & 6.7 & 4.3 & 38.4 & 7.4 \\
\hline 2026 & 26.8 & $\mathbf{8 . 1}$ & 12.8 & 3.7 & 7.6 & 4.9 & 38.4 & 7.3 \\
\hline 2028 & 26.7 & $\mathbf{8 . 6}$ & 13.9 & 4.0 & 8.5 & 5.5 & 38.4 & 7.2 \\
\hline 2030 & 26.7 & $\mathbf{9 . 3}$ & 14.9 & 4.2 & 9.5 & 6.1 & 38.4 & 7.2 \\
\hline
\end{tabular}

Table 8: Cost of all Scenarios in Million US dollar

\begin{tabular}{|c|c|c|c|c|c|c|c|c|c|c|}
\hline Years & 2012 & 2014 & 2016 & 2018 & 2020 & 2022 & 2024 & 2026 & 2028 & 2030 \\
\hline \multicolumn{11}{|c|}{ BAU Scenario } \\
\hline Capital Cost & 151.9 & 418.0 & 638.8 & 804.5 & 729.7 & 661.9 & 600.3 & 544.5 & 493.9 & 488.0 \\
\hline Externality Cost & \begin{tabular}{|l|}
1866.4 \\
\end{tabular} & 2197.0 & 2556.2 & 2588.7 & 2466.3 & 2325.9 & 2212.5 & 2126.4 & 2086.9 & 2082.7 \\
\hline Fuel Cost & \begin{tabular}{|l|}
5122.4 \\
\end{tabular} & 3360.0 & 3148.9 & 2769.0 & 2763.7 & 2691.7 & 2682.7 & 2791.9 & 3128.6 & 3662.8 \\
\hline $\begin{array}{ll}\text { Fixed } & \text { O\&M } \\
\text { Cost } & \\
\end{array}$ & 411.1 & 479.8 & 511.4 & 531.3 & 472.6 & 428.7 & 372.0 & 337.4 & 305.1 & 276.7 \\
\hline Var. O\&M Cost & 278.8 & 309.5 & 336.0 & 385.7 & 353.5 & 329.0 & 307.6 & 289.1 & 274.4 & 262.9 \\
\hline BAU Total Cost & 7830.5 & 6764.1 & 7191.4 & 7052.1 & 6785.9 & 6437.1 & 6175.2 & 6089.4 & 6288.9 & 6733.0 \\
\hline $\begin{array}{l}\text { BAU } \\
\text { cost/MTOE }\end{array}$ & \begin{tabular}{|l|}
1204.69 \\
\end{tabular} & 1009.57 & 1057.559 & 1007.44 & 942.486 & 869.88 & 801.97 & 751.78 & 731.27 & 723.98 \\
\hline \multicolumn{11}{|c|}{ Green Pakistan } \\
\hline Capital Cost & \begin{tabular}{|l|}
60.9 \\
\end{tabular} & 162.7 & 241.6 & 301.2 & 344.7 & 375.8 & 396.9 & 409.5 & 415.3 & 415.5 \\
\hline Externality Cost & - & - & - & - & - & - & - & - & - & - \\
\hline Fuel Cost & - & - & - & - & - & - & - & - & - & - \\
\hline Fixed O\&M & 105.3 & 128.6 & 132.2 & 147.1 & 158.1 & 165.8 & 170.7 & 173.3 & 173.9 & 172.9 \\
\hline Variable O\&M & 125.9 & 138.7 & 127.4 & 133.7 & 136.9 & 138.7 & 138.7 & 137.2 & 134.5 & 131.0 \\
\hline GP Total Cost & 292.1 & 430.0 & 501.2 & 582.0 & 639.8 & 680.4 & 706.3 & 720.0 & 723.8 & 719.4 \\
\hline GP Cost/MTOE & \begin{tabular}{|l|}
121.708 \\
\end{tabular} & 159.259 & 200.48 & 215.556 & 213.267 & 212.62 & 201.8 & 194.59 & 180.95 & 171.28 \\
\hline \multicolumn{11}{|c|}{ Nuclear Scenario } \\
\hline Capital Cost & \begin{tabular}{|c|}
99.2 \\
\end{tabular} & 272.1 & 414.6 & 530.6 & 623.7 & 695.1 & 747.5 & 783.8 & 806.6 & 818.2 \\
\hline Externality Cost & - & - & - & - & - & - & - & - & - & - \\
\hline Fuel Cost & 239.3 & 367.2 & 461.0 & 526.7 & 553.6 & 598.6 & 630.5 & 651.3 & 662.8 & 666.5 \\
\hline Fixed O\&M & 108.4 & 171.2 & 221.3 & 260.7 & 282.7 & 305.8 & 322.1 & 332.7 & 338.5 & 340.4 \\
\hline Variable O\&M & \begin{tabular}{|l|l|}
73.8 \\
\end{tabular} & 128.9 & 182.6 & 233.9 & 274.0 & 296.3 & 312.1 & 322.4 & 328.1 & 329.9 \\
\hline NS Total Cost & \begin{tabular}{|l|}
520.7 \\
\end{tabular} & 939.3 & 1279.5 & 1551.8 & 1734.1 & 1895.8 & 2012.2 & 2090.2 & 2136.1 & 2155.1 \\
\hline NS Cost/MTOE & \begin{tabular}{|l|}
650.875 \\
\end{tabular} & 670.929 & 639.75 & 596.846 & 559.387 & 512.38 & 467.95 & 426.57 & 388.38 & 353.29 \\
\hline \multicolumn{11}{|c|}{ Optimization } \\
\hline Capital Cost & 1632.5 & 1696.7 & 1651.2 & 1497.7 & 1358.4 & 1232.1 & 1117.6 & 1013.7 & 919.4 & 833.9 \\
\hline Externality Cost & \begin{tabular}{|l|}
71.8 \\
\end{tabular} & 40.4 & 49.6 & 67.7 & 51.9 & 39.6 & 29.2 & 21.3 & 15.3 & 10.4 \\
\hline Fuel Cost & 225.8 & 143.2 & 161.1 & 200.4 & 159.6 & 126.4 & 98.4 & 75.8 & 57.8 & 42.6 \\
\hline Fixed O\&M & 525.5 & 499.6 & 465.1 & 421.8 & 382.6 & 347.0 & 314.8 & 285.5 & 259.0 & 234.9 \\
\hline Variable O\&M & 326.9 & 320.9 & 314.3 & 297.6 & 273.0 & 248.4 & 225.9 & 205.4 & 186.5 & 169.4 \\
\hline OPT Total Cost & 2782.6 & 2700.8 & 2641.2 & 2485.2 & 2225.5 & 1993.5 & 1785.9 & 1601.7 & 1438.0 & 1292.2 \\
\hline
\end{tabular}




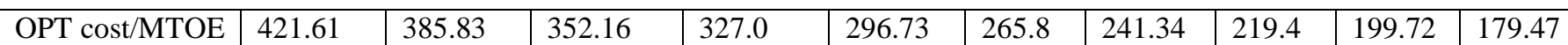

Table 9: Coal mining, oil renining, natural gas and LPG production supply forecast in MTOE

\begin{tabular}{|l|l|l|l|l|l|l|l|l|l|l|}
\hline Yranches & 2012 & 2014 & 2016 & 2018 & 2020 & 2022 & 2024 & 2026 & 2028 & 2030 \\
\hline Coal Mining & 8.7 & 12.1 & 14.7 & 16.3 & 16.6 & 16.8 & 17.2 & 17.5 & 18.0 & 18.5 \\
\hline Natural gas Production & 33.6 & 33.2 & 34.1 & 35.6 & 39.7 & 45.0 & 51.9 & 60.9 & 72.5 & 87.8 \\
\hline LPG Production & 0.4 & 0.4 & 0.4 & 0.5 & 0.5 & 0.5 & 0.6 & 0.6 & 0.6 & 0.6 \\
\hline Oil Refining & 15.0 & 18.8 & 18.8 & 18.8 & 18.8 & 18.8 & 18.8 & 18.8 & 18.8 & 18.8 \\
\hline Total & 57.7 & 64.5 & 68.0 & 71.2 & 75.6 & 81.2 & 88.5 & 97.8 & 109.9 & 125.7 \\
\hline
\end{tabular}

\section{Highlights:}

- The renewable energy policy is examined

- Four Scenarios named Business as usual, Green Pakistan, Nuclear and optimization have been developed.

- The analysis shows to emphasize more on renewable resources for sustainable future supply. 